\title{
Synthesis of Glucuronoxylan Hexasaccharides by Preactivation-Based Glycosylations
}

\author{
Underlin, Emilie Nørmølle; d'Errico, Clotilde; Böhm, Maximilian Felix; Madsen, Robert
}

Published in:

European Journal of Organic Chemistry

Link to article, DOI:

10.1002/ejoc.202000211

Publication date:

2020

Document Version

Peer reviewed version

Link back to DTU Orbit

Citation (APA):

Underlin, E. N., d'Errico, C., Böhm, M. F., \& Madsen, R. (2020). Synthesis of Glucuronoxylan Hexasaccharides by Preactivation-Based Glycosylations. European Journal of Organic Chemistry, 20, 3050-3058.

https://doi.org/10.1002/ejoc.202000211

\section{General rights}

Copyright and moral rights for the publications made accessible in the public portal are retained by the authors and/or other copyright owners and it is a condition of accessing publications that users recognise and abide by the legal requirements associated with these rights.

- Users may download and print one copy of any publication from the public portal for the purpose of private study or research.

- You may not further distribute the material or use it for any profit-making activity or commercial gain

- You may freely distribute the URL identifying the publication in the public portal 


\section{EurJOC}

European Journal of Organic Chemistry

\section{Phemistry Europe}

European Chemical Societies Publishing

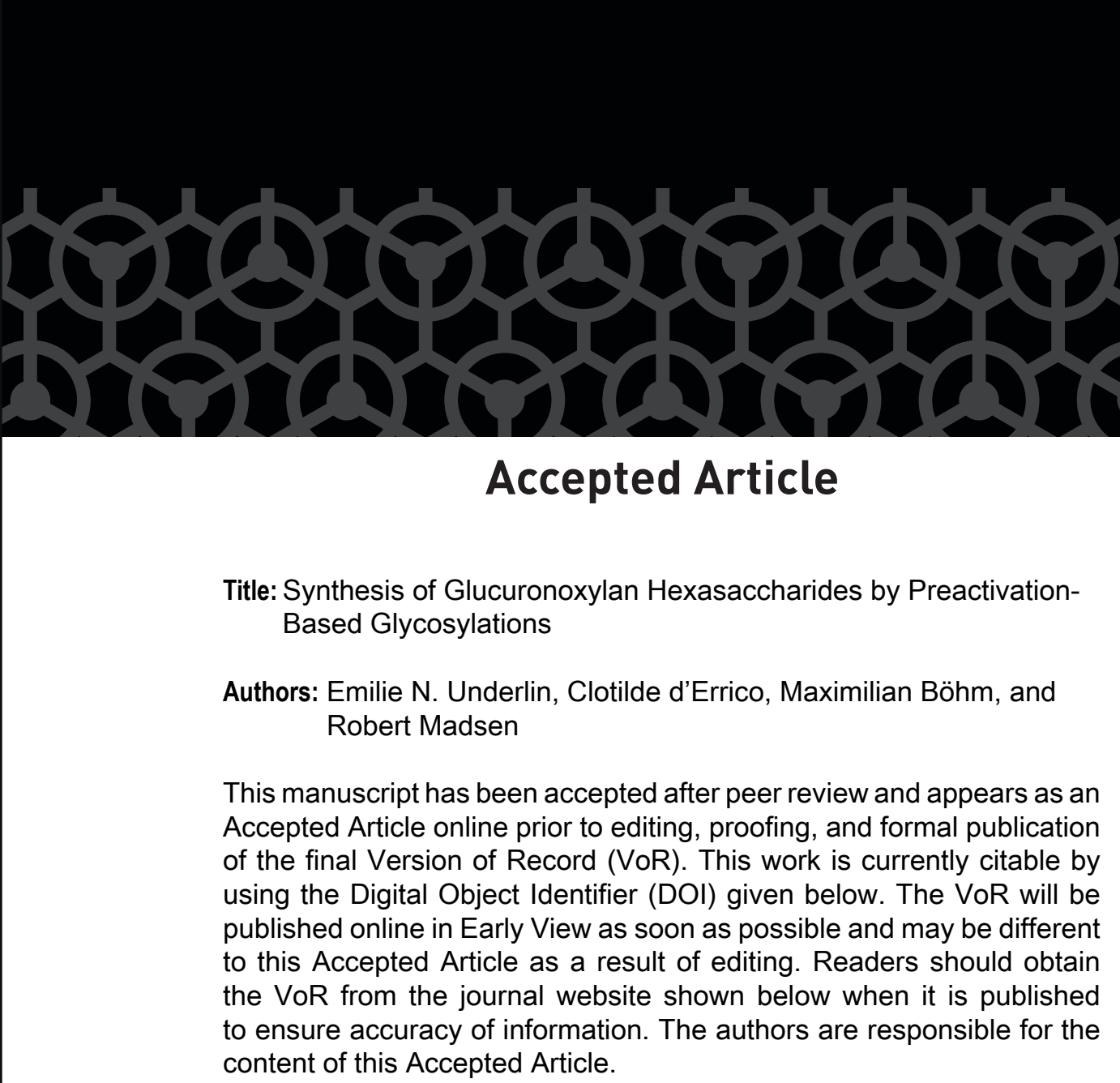

To be cited as: Eur. J. Org. Chem. 10.1002/ejoc.202000211

Link to VoR: https://doi.org/10.1002/ejoc.202000211 


\title{
Synthesis of Glucuronoxylan Hexasaccharides by Preactivation- Based Glycosylations
}

\author{
Emilie N. Underlin ${ }^{[a]}$ Clotilde d'Errico, ${ }^{[a]}$ Maximilian Böhm, ${ }^{[a]}$ and Robert Madsen ${ }^{[a]}$
}

[a] Dr. E. N. Underlin, Dr. C. d'Errico, Dr. M. Böhm, Prof. Dr. R. Madsen

Department of Chemistry, Technical University of Denmark

2800 Kgs. Lyngby (Denmark)

E-mail: rm@kemi.dtu.dk

https://www.kemi.dtu.dk

Supporting information for this article is given via a link at the end of the document.

\begin{abstract}
The synthesis of two glucuronoxylans is described, which both consist of a pentaxylan backbone and a glucuronic acid linked to the 2 position in the fourth xylose residue from the reducing end. The two target molecules differ in the 4 position of the glucuronic acid where one is unsubstituted while the other contains a methyl ether. The pentaxylan backbone is assembled in four glycosylation reactions with phenyl thioglycoside donors. The couplings are performed by preactivation of the donor with in situ-generated $p$ nitrobenzenesulfenyl triflate prior to addition of the acceptor. The glucuronic acids are then attached by Koenigs-Knorr glycosylations followed by deprotections. The syntheses employ a total of 8 steps from monosaccharide building blocks and afford the two glucuronoxylans in 12 and $15 \%$ overall yield. The hexasaccharide products are valuable substrates for investigating the activity and specificity of glucuronoxylan-degrading enzymes.
\end{abstract}

\section{Introduction}

Hemicellulose is composed of a diverse group of polysaccharides where some of the most abundant oligomers are $\beta(1 \rightarrow 4)$-linked xylans decorated with arabinose and glucuronic acid substituents. ${ }^{[1]}$ The hydroxy group at position 4 of the glucuronic acids may be methylated and the uronic acids are attached by $\alpha$-linkages to the 2-position of the xylose residues. In hardwoods, glucuronoxylans are the main hemicellulosic polysaccharide accounting for $15-30 \%$ of the total weight. ${ }^{[2]}$ The ratio between the xylose and the glucuronic acid residues is typically around 7:1 depending on the hardwood source. ${ }^{[2]}$ In softwoods, cereals and grasses, glucuronoxylans are further decorated with arabinose substituents to form glucuronoarabinoxylans as the major hemicellulosic polysaccharide. ${ }^{[1]}$

The $\beta(1 \rightarrow 4)$ xylose linkages in glucuronoxylans are hydrolyzed by xylanases from glycoside hydrolase $(\mathrm{GH})$ families 10, 11 and $30 .{ }^{[3]}$ The substrate specificity for the three enzyme classes differs depending on the position of the glucuronic acid. GH10 xylanases require two consecutive unsubstituted xylose residues and are able to cleave the linkage to the glucuronic acid-bound xylose from the non-reducing end. ${ }^{[3]}$ GH11 xylanases need three continuous unsubstituted xylose units and can hydrolyze the xylan chain one linkage before the glucuronic acid-containing xylose. ${ }^{[3]} \mathrm{GH} 30$ xylanases are specific for glucuronoxylans where cleavage occurs at the second glycosidic linkage towards the reducing end from the glucuronic acidbound xylose..$^{[3]}$ The chemically strong $\alpha$-linkage to glucuronic acid can be hydrolyzed by $\mathrm{GH} 67$ and $\mathrm{GH} 115 \alpha$-glucuronidases where the former only removes glucuronic acid from terminal non-reducing end xylose residues while the latter can also cleave internally bound substituents. ${ }^{[3]}$ GH67 $\alpha$-glucuronidases are selective for 4 -O-methylglucuronic acid $^{[4]}$ while $\mathrm{GH} 115 \alpha$ glucuronidases and $\mathrm{GH} 30$ xylananses are able to act on both glucuronic acid- and 4-O-methylglucuronic acid-containing substrates. ${ }^{[5]}$ In principle, the combination of xylanases and $\alpha$ glucuronidases should completely degrade glucuronoxylan polysaccharides, but in reality this does often not occur..$^{[3]}$ Instead, a variety of small glucuronoxylan oligosaccharides remain after pretreatment, hydrolysis and fermentation of lignocellulose and in some cases these recalcitrant carbohydrates can be recovered in large amounts. ${ }^{[6]}$

A problem in the study of xylanases and $\alpha$-glucuronidases is the lack of well-defined and pure substrates to investigate the activity and the specificity. Mild acidic hydrolysis of glucuronoxylan gives rise to a mixture of oligosaccharides, which mostly contain two to eight xylose units and one glucuronic acid per chain. ${ }^{[7]}$ Enzymatic hydrolysis of glucuronoxylans and glucuronoarabinoxylans followed by extensive chromatographic purification makes it possible to isolate pure oligosaccharides containing a tri- or a tetraxylan backbone and a glucuronic acid bound to the third xylose residue. ${ }^{[8]}$ Only in one case has it been possible to isolate small amounts of a pentaxylan with a glucuronic acid bound to xylose number three. ${ }^{[9]}$

Chemical synthesis offers a solution to this supply problem, but glucuronoxylans have so far received very little attention. ${ }^{[10]}$ In four cases, glucuronoxylan di- and trisaccharides have been prepared by glycosylating a glucuronic acid donor onto a xylose or a xylobiose acceptor. ${ }^{[11]}$ The coupling with the uronic acid was performed by using either the Koenigs-Knorr, the imidate or the thioglyccoside glycosylation method. ${ }^{[11]}$ Only in one case has a pentasaccharide been prepared by glycosylating a glucuronosyl chloride onto a branched tetraxylan. ${ }^{[12]}$

We have recently presented a short synthetic strategy to prepare arabinoxylans ${ }^{[13]}$ where the xylan backbone is assembled by a preactivation-based approach. ${ }^{[14]}$ In this protocol a protected phenyl 1-thioxylopyranoside is activated by in situgenerated $p$-nitrobenzenesulfenyl triflate ${ }^{[15]}$ and glycosylated 
onto a partially protected phenyl 1-thioxylopyranoside acceptor. The procedure is then repeated until the desired xylan is prepared. ${ }^{[13]}$ In this way, a linear xylan backbone is assembled without using any deprotection step for each glycosylation reaction. ${ }^{[13,16]}$ We envisioned that the strategy could be extended to the synthesis of glucuronoxylans by coupling a glucuronic acid to the xylan backbone. Glycosylations with uronic acids, although, are often a challenge due to their low reactivity as donors. ${ }^{[17]}$ Overall, two distinct approaches are often used, which both start from the corresponding hexose. ${ }^{[17]}$ In the first approach, the hexose is protected and oxidized to the uronic acid, which is then used for the coupling ${ }^{[17]}$ as shown in the above syntheses of glucuronoxylans. ${ }^{[11,12]}$ In the second approach, the coupling is carried out with the more reactive hexose as the donor followed by oxidation of the product at $\mathrm{C}$ 6. ${ }^{[17]}$ We have previously used this latter approach in our syntheses of pectic oligosaccharides for introducing galacturonic acids. ${ }^{[18]}$

Herein, we present the synthesis of glucuronoxylans $\mathbf{1}$ and $\mathbf{2}$, which both contain a pentaxylan backbone and a glucuronic acid at xylose number four (Figure 1). The only difference is the absence (as in 1) or presence (as in 2) of the 4-O-methyl group, which renders the substrates suitable for investigating the influence of this ether moiety. The position of the glucuronic acid and the length of the xylan backbone are chosen to ensure sufficient enzyme activities with xylanases and $\alpha$ glucuronidases. ${ }^{[19]}$

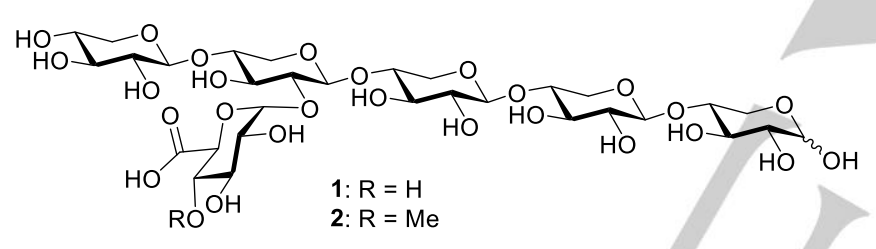

Figure 1. Structure of target glucuronoxylans $\mathbf{1}$ and $\mathbf{2}$.

\section{Results and Discussion}

The pentaxylan backbone will be assembled from four different xylose building blocks by the use of the preactivation-based glycosylations. As demonstrated in our arabinoxylan syntheses, ${ }^{[13]}$ the benzoyl group will serve as a permanent protecting group for xylose hydroxy groups not involved in the glycosylations while the levulinoyl (Lev) group will function as a temporary protecting group at the position where the glucuronic acid will be installed. The benzoyl and levulinoyl groups are both ester protecting groups and thus ensure neighboring group participation in the glycosylations to form the $\beta$-linkages.
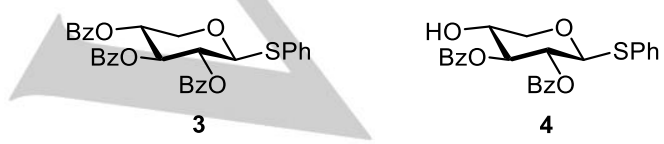

Figure 2. Benzoylated xylose building blocks 3 and 4 .
Benzoylated thioglycosides $\mathbf{3}$ and $\mathbf{4}$ were prepared in our earlier work (Figure 2) ${ }^{[13]}$ where the latter was synthesized from phenyl 1-thio- $\beta$-D-xylopyranoside through 2,3-O-isopropylidene and 4-O-p-methoxybenzyl (PMB) protection followed by deprotection and benzoylation. The intermediate phenyl 4-O- $(p-$ methoxy)benzyl-1-thio- $\beta$-D-xylopyranoside $(5)^{[13]}$ was selected as the starting material to prepare building block 6 with a levulinoyl and a benzoyl group at position 2 and 3 , respectively (Scheme 1). Attempts to perform a selective levulinoyl protection at the 2 position in $\mathbf{5}$ were unsuccessful.[20] Various conditions with levulinoyl chloride, levulinic acid and levulinic anhydride were investigated, but either led to very little conversion or a mixture of the two levulinate regioisomers. Selective benzoylation of the 3 position in $\mathbf{5}$ with benzoyl chloride under different conditions were also fruitless since the 2-O-benzoylated regioisomer was obtained as the major product in all cases. ${ }^{[20]}$ Instead, it was decided to divert to a temporary silyl-protection of diol $\mathbf{5}$ based on a report with the corresponding selenoglycoside, which was shown to undergo a highly regioselecive TBS-protection at position 3 with TBSOTf and lutidine in THF at $-78^{\circ} \mathrm{C} . .^{[21]}$ When these conditions were applied to the sulfur analogue 5, the 3-OTBS-protected product was obtained in $84 \%$ yield as the sole product. The 2-hydroxy group was then esterified with levulinic acid, DMAP and DCC to afford fully protected xyloside 7 . The subsequent cleavage of the TBS group was first attempted with TBAF, but in the absence of a stoichiometric acid, the TBS and the levulinoyl groups were both cleaved while no reaction occurred with TBAF in the presence of an excess of acetic acid. Finally, the use of a $20 \%$ aqueous solution of HF in acetonitrile affected a clean removal of the TBS ether to afford alcohol 8 in $91 \%$ yield. The hydroxy group was benzoylated and excess benzoyl chloride removed with 3-(dimethylamino)-1-propylamine (DMAPA). ${ }^{[22]}$ Without further purification, the crude product was submitted to PMB deprotection with DDQ to give building block 6 .

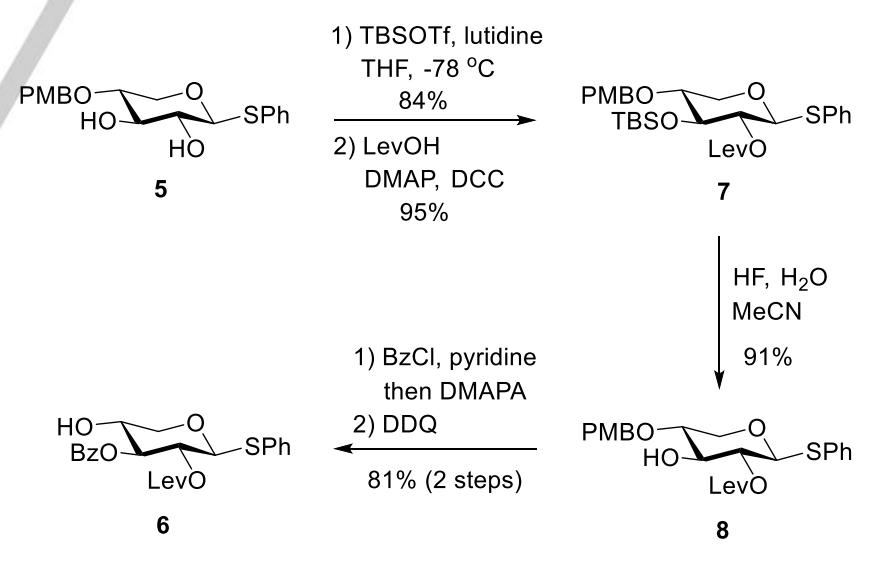

Scheme 1. Synthesis of xylose building block 6 .

It was decided to install a benzyl group at the anomeric center in the xylose unit at the reducing end since a phenyl thioglycoside may not be compatible with the glucuronic acid glycosylations (vide infra). The necessary building block 9 was prepared from phenyl 2,3-di-O-benzoyl-4-O-( $p$-methoxy)benzyl1-thio- $\beta$-D-xylopyranoside $(\mathbf{1 0})^{[13]}$ by glycosylation with benzyl alcohol in the presence of NIS and triflic acid followed by PMB removal with DDQ (Scheme 2). 


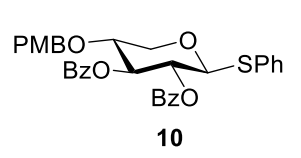

1) $\mathrm{BnOH}, \mathrm{NIS}, \mathrm{TfOH}$
$\underset{78 \%}{2}$
2) $\mathrm{DDQ}, 89 \%$

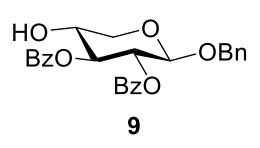

Scheme 2. Synthesis of xylose building block 9 .

With the xylose building blocks in hand the stage was now set to assemble the pentaxylan backbone by preactivationbased glycosylation with in situ-generated $p$ nitrobenzenesulfenyl triflate as the promoter. The coupling between monosaccharides 3 and 6 gave exclusively disaccharide 11, which was isolated in $89 \%$ yield (Scheme 3 ). As noted in our earlier study, it is important to keep the temperature low during the glycosylation. ${ }^{[13]}$ Therefore the coupling reactions were carried out by first activating the donor thioglycoside at a temperature below $-60{ }^{\circ} \mathrm{C}$ for $10 \mathrm{~min}$ with $p$ nitrobenzenesulfenyl chloride and silver triflate, which was followed by addition of the acceptor thioglycoside and stirring at a temperature around $-55^{\circ} \mathrm{C}$ until the glycosylation had gone to completion according to TLC analysis. Using this protocol, the following two consecutive glycosylations with acceptor 4 proceeded in 68 and $79 \%$ yield, respectively, to afford trisaccharide 12 and tetrasaccharide 13. It should be noted that the glycosylation with the 2-O-levulinoyl-protected donor $\mathbf{1 1}$ gave a slightly lower yield than when 2-O-benzoyl-protected donors 3 and 12 were employed. The same observation was made during our previous work where the highest yields were obtained with 2-O-benzoyl-protected donors, ${ }^{[13]}$ which may be due to the higher stability of the activated intermediate (i.e. the 1,2-benzoxonium ion ${ }^{[23]}$ in this case. At last, tetrasaccharide $\mathbf{1 3}$ was coupled with the reducing end xylose building block 9 to afford pentasaccharide $\mathbf{1 4}$ in $83 \%$ yield. Subsequent removal of the levulinoyl group with hydrazine afforded the corresponding alcohol 15 in near quantitative yield. The $\beta$-linkages in 15 were confirmed by measuring the $J_{\mathrm{C} 1, \mathrm{H} 1}$ coupling constants, which were located around $162-165 \mathrm{~Hz}$ and thus characteristic for $\beta$ xylopyranosides. ${ }^{[24]}$

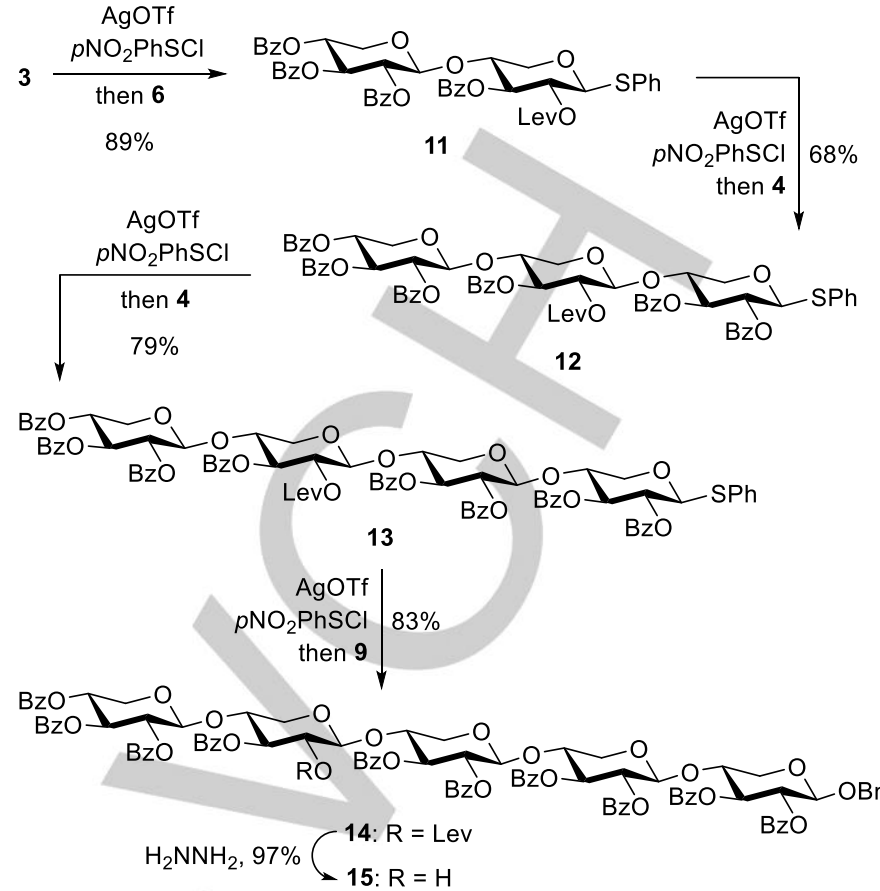

Scheme 3. Synthesis of pentaxylan backbone 15.

To assemble glucuronoxylans $\mathbf{1}$ and $\mathbf{2}$ the next step will involve a glycosylation between pentaxylan $\mathbf{1 5}$ and a glucose or a glucuronic acid donor. It was decided to use the latter approach, which has provided moderate-to-good yields and selectivities in the coupling with different uronic acid donors to xylose, xylobiose and xylotetraose acceptors. ${ }^{[11,12]}$ The best result was obtained by using an ethyl thioglycoside donor and performing the coupling with dimethyl(methylthio)sulfonium triflate (DMTST) as the promoter in diethyl ether. ${ }^{[11 a, 25]}$ Since thioglycosides can also be converted into other donors, it was decided to use this building block for attaching the glucuronic acid residue. An ether protecting group will be necessary at the 2 position to favor formation of the desired $\alpha$-linkage. Thus, uronic acid building blocks $16^{[26]}$ and $17^{[11 \mathrm{a}]}$ were prepared from ethyl 1-thio- $\beta$-D-glucopyranoside by slight modification of literature protocols (Figure 3). ${ }^{20]}$

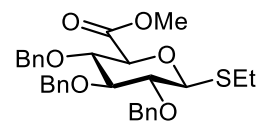

16

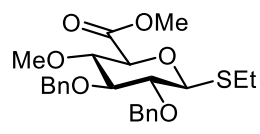

17
Figure 3. Glucuronic acid donors 16 and $\mathbf{1 7}$

The pivotal glycosylation with acceptor 15 was first investigated with DMTST as the promoter (Table 1 and Scheme 4). Disappointingly, the reaction between 17 and 15 was very slow and mainly led to decomposition of donor 17 (entry 1). Changing the promoter to the more reactive combination of NIS and TESOTf led to a faster conversion, but in this case only decomposition of 17 was observed (entry 2). The promoter system from Scheme 3 was then investigated and subjecting 17 
and 15 to $p$-nitrobenzenesulfenyl chloride and silver triflate actually produced the desired hexasaccharide 19 in $61 \%$ yield, but unfortunately as an almost equal mixture of the $\alpha$ - and the $\beta$ glucuronide (entry 3). Consequently, it appears that the direct coupling with the ethyl thioglycosides of the uronic acids is very challenging and it was therefore decided to convert 16 and 17 into another donor. An easy transformation is the titration of thioglycosides with molecular bromine in dichloromethane to form the corresponding $\alpha$-glycosyl bromides, which can then be 17 followed by reaction with 15 and silver triflate afforded hexasaccharide 19 in $42 \%$ yield as a 3:2 $\alpha / \beta$ mixture (entry 4 ). Another silver salt, which often gives a better $\alpha$ selectivity in Koenigs-Knorr glycosylations, is silver perchlorate and especially when it is dissolved in ether. ${ }^{[27]}$ Using this protocol hexasaccharide 19 was isolated in $44 \%$ yield and with an improved $\alpha / \beta$ selectivity of $5: 2$ (entry 5 ). When the same sequence was applied to donor 16, the corresponding hexasaccharide 18 was obtained in $45 \%$ yield with an $\alpha / \beta$ ratio of $4: 1$ (entry 6 ). In both cases, a significant amount of unreacted acceptor 15 was recovered and it was therefore decided to continue the syntheses with these silver perchlorate glycosylations. The $\alpha$ stereochemistry of the major isomer in $\mathbf{1 8}$ and 19 was established from the $\mathrm{H}-1$ and $\mathrm{C}-1$ chemical shifts of the glucuronic acid moiety ${ }^{[28]}$ as well as the measurement of the $J_{\mathrm{C} 1, \mathrm{H} 1}$ coupling constants, which in both cases were around 173 $\mathrm{Hz} \cdot{ }^{[29]}$ used directly in a Koenigs-Knorr glycosylation. Thus, titration of

were removed by hydrogenolysis with Degussa-type palladiumon-carbon to afford fully deprotected target structures $\mathbf{1}$ and $\mathbf{2}$ with the same $\alpha / \beta$ glucuronic acid ratio as in Table 1 , entry 5 and 6 . The minor amounts of the $\beta$-glucuronides should not influence the subsequent studies with the target molecules. An alternative synthesis strategy would be to introduce the glucuronic acid earlier on trisaccharide 12 instead of on pentasaccharide 14. Although not attempted, it may have resulted in a more straightforward purification of the glucuronides. The overall yields of $\mathbf{1}$ and $\mathbf{2}$ from the monosaccharide building blocks were 15 and $12 \%$, respectively, over a total of 8 steps.

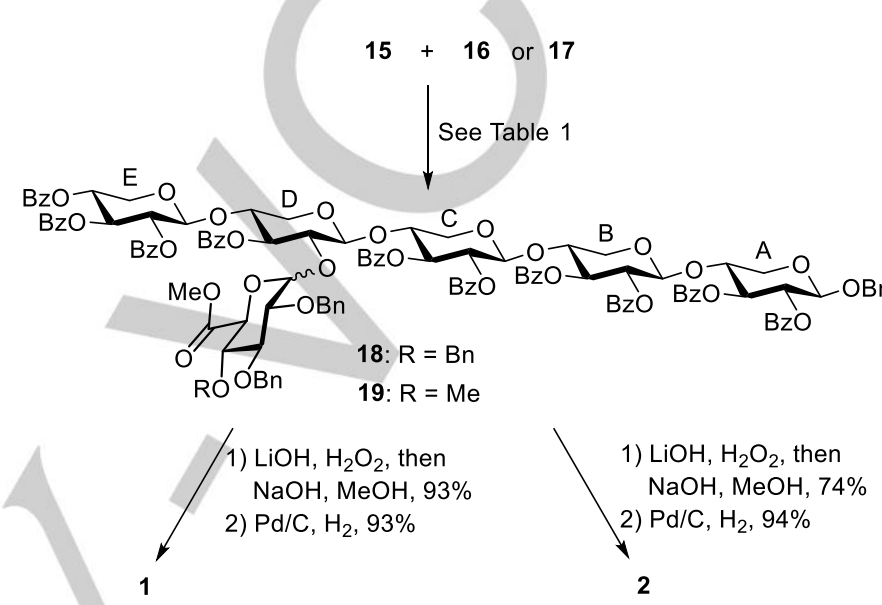

Table 1. Glycosylation of Acceptor 15 with Donors 16 and 17.

\begin{tabular}{|c|c|c|c|c|c|}
\hline Entry & Donor & Conditions & Product & $\begin{array}{l}\text { Yield } \\
{[\%]}\end{array}$ & $\alpha: \beta$ \\
\hline 1 & 17 & DMTST, $\mathrm{Et}_{2} \mathrm{O}, 0^{\circ} \mathrm{C}, 20 \mathrm{~h}$ & _[a] & & \\
\hline 2 & 17 & $\begin{array}{l}\mathrm{NIS}, \mathrm{TESOTf}, \mathrm{CH}_{2} \mathrm{Cl}_{2}, \mathrm{Et}_{2} \mathrm{O} \\
-10^{\circ} \mathrm{C}, 1 \mathrm{~h}\end{array}$ & ${ }^{[\mathrm{a}]}$ & & \\
\hline 3 & 17 & $\begin{array}{l}\mathrm{pNO}_{2} \mathrm{PhSCl}, \mathrm{AgOTf}, \mathrm{CH}_{2} \mathrm{Cl}_{2} \\
-40^{\circ} \mathrm{C}, 20 \mathrm{~min}\end{array}$ & 19 & & $1: 0$ \\
\hline 4 & 17 & $\begin{array}{l}\mathrm{Br}_{2}, \mathrm{CH}_{2} \mathrm{Cl}_{2} \text {, then } 15, \text { AgOTf, } \\
-30^{\circ} \mathrm{C}, 1 \mathrm{~h}\end{array}$ & 19 & 42 & $3: 2$ \\
\hline 5 & 17 & $\begin{array}{l}\mathrm{Br}_{2}, \mathrm{CH}_{2} \mathrm{Cl}_{2} \text {, then } 15, \mathrm{AgClO}_{4} \text {, } \\
\mathrm{Et}_{2} \mathrm{O},-30^{\circ} \mathrm{C}, 1.5 \mathrm{~h}\end{array}$ & 19 & $44^{[b]}$ & $5: 2$ \\
\hline 6 & 16 & $\begin{array}{l}\mathrm{Br}_{2}, \mathrm{CH}_{2} \mathrm{Cl}_{2} \text {, then } 15, \mathrm{AgClO}_{4} \\
\mathrm{Et}_{2} \mathrm{O},-30^{\circ} \mathrm{C}, 2 \mathrm{~h}\end{array}$ & 18 & $45^{[c]}$ & $4: 1$ \\
\hline
\end{tabular}

[a] Decomposition of 17 . [b] $17 \%$ of 15 recovered. [c] $23 \%$ of 15 recovered.

It was not possible to separate the $\alpha$ - and the $\beta$-glucuronide in 18 and 19 by flash chromatography and the following deprotections were therefore carried out on the mixtures. It was first attempted to perform a Zemplén deprotection of the benzoyl groups, but this transformation turned out to be rather slow and led to partial epimerization at position 5 in the D-glucuronic acids to give L-iduronic acid. To prevent this side reaction, the methyl ester was first removed with lithium hydroxide and hydrogen peroxide, ${ }^{[30]}$ which was then followed by the Zemplén reaction to cleave the benzoates (Scheme 4). The products were purified through a short reverse-phase column, but the $\alpha$ - and the $\beta$ glucuronide could not be separated. Finally, the benzyl groups
Scheme 4. Synthesis of glucuronoxylans 1 and 2 .

\section{Conclusion}

In summary, we have described a concise synthetic route to glucuronoxylans $\mathbf{1}$ and $\mathbf{2}$ by the use of preactivation-based glycosylations to assemble the xylan backbone. The glucuronic acids are introduced through Koenigs-Knorr glycosylations to afford the $\alpha$ anomers as the major products. Hexasaccharides 1 and 2 constitute the largest glucuronoxylans synthesized to date and are valuable substrates for studying the activity and the specificity of hemicellulose-degrading enzymes.

\section{Experimental Section}

General Information: Starting materials, reagents, and solvents were purchased from commercial suppliers and used without further purification unless otherwise noted. All solvents used were of analytical HPLC grade. Anhydrous solvents were obtained from an Innovative Technology PS-MD-7 PureSolv solvent purification system except for dichloromethane and toluene for glycosylations, which were dried over 3 $\AA$ molecular sieves. Air and moisture sensitive experiments were conducted under inert atmosphere $\left(\mathrm{N}_{2}\right)$ in dried glassware and anhydrous solvents. The water content was checked on an 899 Coulometer from Metrohm. Crushed $3 \AA$ molecular sieves for glycosylations were stored in the oven at $110^{\circ} \mathrm{C}$ before being activated by heating under vacuum. Thin-layer chromatography (TLC) was carried out using Merck Aluminium Sheets pre-coated with $0.25 \mathrm{~mm}$ silica gel, C$60 \mathrm{~F}_{254}$ plates. Compounds were visualized under UV light or by charring after dipping in a cerium ammonium sulfate solution (1\% cerium(IV)sulfate and $2.5 \%$ ammonium heptamolybdate in a $10 \%$ sulfuric acid solution). Flash column chromatography was performed using Merck 
Geduran silica gel $60 \AA(40-63 \mu \mathrm{m})$ as the stationary phase. NMR spectra were recorded on a Bruker Ascend 400 or a Bruker Ascend 800 spectrometer. Chemical shifts are reported in part per million (ppm) relative to the residual solvent peak in $\mathrm{CDCl}_{3}(\delta \mathrm{H}=7.26 \mathrm{ppm}, \delta \mathrm{c}=77.16$ $\mathrm{ppm})$ and $\mathrm{D}_{2} \mathrm{O}(\delta \mathrm{H}=4.79 \mathrm{ppm})$. Coupling constants $(\mathcal{J})$ are reported in $\mathrm{Hz}$. Assignment of ${ }^{1} \mathrm{H}$ and ${ }^{13} \mathrm{C}$ resonances were based on APT, DQF-COSY, HSQC, H2BC, HMBC, TOCSY, and HSQC-TOSCY experiments when needed. Xylose residues are labelled $A-E$ from the reducing end as shown in Scheme 4. Optical rotation was measured on a Perkin Elmer Model 341 Polarimeter. HRMS analysis was performed on either a UHPLC-QTOF system (Dionex ultimate 3000 and Bruker MaXis) with an electrospray ionization (ESI) source or a MALDI-TOF system (Bruker Solarix XR 7T).

Phenyl 3-O-tert-butyldimethylsilyl-2-O-levulinoyl-4- $O$ - $(p$ methoxy)benzyl-1-thio- $\beta$-D-xylopyranoside (7): Diol $5^{[13]}(1.000 \mathrm{~g}, 2.76$ $\mathrm{mmol})$ was dissolved in dry THF $(30.0 \mathrm{~mL})$ and cooled to $-78^{\circ} \mathrm{C}$. 2,6 Lutidine $(0.482 \mathrm{~mL}, 4.14 \mathrm{mmol})$ and TBSOTf $(0.761 \mathrm{~mL}, 3.31 \mathrm{mmol})$ were added followed by stirring for $20 \mathrm{~min}$ until TLC (heptane/EtOAc 1:1) showed full conversion. The reaction was diluted with $\mathrm{CH}_{2} \mathrm{Cl}_{2}$ and washed with $\mathrm{H}_{2} \mathrm{O}$. The organic phase was dried over $\mathrm{Na}_{2} \mathrm{SO}_{4}$, filtered and conc. in vacuo. The crude product was purified by flash column chromatography (heptane/EtOAc 10:1) to obtain phenyl 3-O-tertbutyldimethylsilyl-4-O-( $p$-methoxy)benzyl-1-thio- $\beta$-D-xylopyranoside as a clear oil $(1.110 \mathrm{~g}, 84 \%) . R_{\mathrm{f}}=0.28$ (heptane/EtOAc 9:1). $[\alpha]^{25}=-130.2(c$ $\left.0.083, \mathrm{CHCl}_{3}\right) .{ }^{1} \mathrm{H}$ NMR $\left(400 \mathrm{MHz}, \mathrm{CDCl}_{3}\right): \delta=7.49-7.47(\mathrm{~m}, 1 \mathrm{H}), 7.30$ $7.20(\mathrm{~m}, 7 \mathrm{H}), 6.89-6.87(\mathrm{~m}, 1 \mathrm{H}), 5.20\left(\mathrm{~d}, \mathrm{~J}_{1,2}=3.0 \mathrm{~Hz}, 1 \mathrm{H}, \mathrm{H} 1\right), 4.62(\mathrm{~d}$, $J=11.5 \mathrm{~Hz}, 1 \mathrm{H}, \mathrm{PMB}$ ), 4.53 (d, $J=11.5 \mathrm{~Hz}, 1 \mathrm{H}, \mathrm{PMB}$ ), 4.40 (dd, J5,5' = $\left.12.4 \mathrm{~Hz}, J_{5,4}=1.8 \mathrm{~Hz}, 1 \mathrm{H}, \mathrm{H} 5\right), 3.87$ (t, $\left.J=4.4 \mathrm{~Hz}, 1 \mathrm{H}, \mathrm{H} 3\right), 3.81(\mathrm{~s}, 3 \mathrm{H}$, $\left.\mathrm{OCH}_{3}\right), 3.75(\mathrm{~d}, J=9.4 \mathrm{~Hz}, 1 \mathrm{H}, \mathrm{OH}), 3.70-3.66(\mathrm{~m}, 1 \mathrm{H}, \mathrm{H} 2), 3.62$ (dd, $\left.J_{5,5}^{\prime}=12.4 \mathrm{~Hz}, J_{5,4}=3.7 \mathrm{~Hz}, 1 \mathrm{H}, \mathrm{H} 5^{\prime}\right), 3.34$ (q, J = 5.4 Hz, 1H, H4), 0.93 $(\mathrm{s}, 9 \mathrm{H}), 0.12(\mathrm{~s}, 3 \mathrm{H}), 0.05(\mathrm{~s}, 3 \mathrm{H}) .{ }^{13} \mathrm{C} \mathrm{NMR}\left(101 \mathrm{MHz}, \mathrm{CDCl}_{3}\right): \delta=159.5$, 136.6, $130.8(\times 2), 129.5(\times 2), 129.4,128.8(\times 2), 126.9,114.0(\times 2), 88.9$ (C1), 76.0 (C4), 72.5 (C2), 71.4 (PMB), 69.5 (C3), 59.9 (C5), 55.3 (OMe), 25.8, 18.1, -4.8, -5.0. HRMS: calcd. for $\mathrm{C}_{25} \mathrm{H}_{36} \mathrm{O}_{5} \mathrm{SSiNa}[\mathrm{M}+\mathrm{Na}]^{+}$ 499.1944; found 499.1956. The above alcohol (1.050 g, $2.21 \mathrm{mmol})$ was dissolved in $\mathrm{CH}_{2} \mathrm{Cl}_{2}$ (45.0 mL) followed by addition of DCC $(1.380 \mathrm{~g}, 6.63$ mmol), DMAP $(0.405 \mathrm{~g}, 3.32 \mathrm{mmol})$ and LevOH $(0.340 \mathrm{~g}, 3.32 \mathrm{mmol})$. The reaction was stirred for $2 \mathrm{~h}$ at r.t. where a white precipitate had formed and full conversion was observed by TLC (heptane/EtOAC 1:1). The mixture was filtered through a pad of Celite, the filtrate conc. in vacuo, and the crude product purified by flash column chromatography (heptane/EtOAc 7:1). The product 7 was obtained as a colorless oil $(1.210 \mathrm{~g}, 95 \%) . R_{\mathrm{f}}=0.27$ (heptane/EtOAc 3:2). $[\alpha]_{\mathrm{D}}^{25}=-33.2$ (c 0.28 , $\left.\mathrm{CHCl}_{3}\right) .{ }^{1} \mathrm{H} \mathrm{NMR}\left(400 \mathrm{MHz}, \mathrm{CDCl}_{3}\right): \delta=7.46-7.44(\mathrm{~m}, 2 \mathrm{H}), 7.30-7.23(\mathrm{~m}$, $5 \mathrm{H}), 6.87-6.85(\mathrm{~m}, 2 \mathrm{H}), 4.89-4.85(\mathrm{~m}, 2 \mathrm{H}, \mathrm{H} 1, \mathrm{H} 2), 4.58(\mathrm{~d}, J=11.6 \mathrm{~Hz}$, $1 \mathrm{H}, \mathrm{PMB}), 4.47$ (d, $J=11.6 \mathrm{~Hz}, 1 \mathrm{H}, \mathrm{PMB}), 4.13(\mathrm{q}, J=7.0 \mathrm{~Hz}, 1 \mathrm{H}, \mathrm{H} 5)$, $3.80\left(\mathrm{~s}, 3 \mathrm{H}, \mathrm{OCH}_{3}\right), 3.80-3.77(\mathrm{~m}, 1 \mathrm{H}, \mathrm{H} 3), 3.39-3.33(\mathrm{~m}, 2 \mathrm{H}, \mathrm{H} 4, \mathrm{H} 5)$, 2.78-2.74 (m, 2H), 2.66-2.61 (m, 2H), $2.17(\mathrm{~s}, 3 \mathrm{H}), 0.89(\mathrm{~s}, 9 \mathrm{H}), 0.09(\mathrm{~s}$, $3 \mathrm{H}), 0.06(\mathrm{~s}, 3 \mathrm{H}) .{ }^{13} \mathrm{C} \mathrm{NMR}\left(101 \mathrm{MHz}, \mathrm{CDCl}_{3}\right): \delta=206.2,171.7,159.3$ 135.0, $131.2(\times 2), 130.1,129.5(\times 2), 128.9(\times 2), 127.3,113.8(\times 2), 86.7$ (C1), 76.6 (C4), 72.8 (C2), 72.9 (PMB), 71.8 (C3), 64.4 (C5), 55.3 (OMe), 37.9, 29.9, 28.3, 25.7, 18.0, -4.5, -4.8. HRMS: calcd. for $\mathrm{C}_{30} \mathrm{H}_{42} \mathrm{O}_{7} \mathrm{SSiNa}$ $[\mathrm{M}+\mathrm{Na}]^{+} 597.2312 ;$ found 597.2325 .

Phenyl

2-O-levulinoyl-4-O-(p-methoxy)benzyl-1-thio- $\beta$-Dxylopyranoside (8): A mixture of the silylated xyloside $7(0.100 \mathrm{~g}, 0.17$ $\mathrm{mmol}$ ) in $\mathrm{CH}_{3} \mathrm{CN}(5.0 \mathrm{~mL})$ was cooled to $0^{\circ} \mathrm{C}$. A $20 \% \mathrm{HF}$ solution $(0.30$ $\mathrm{mL}, 3.48 \mathrm{mmol}$ ) was added and the reaction was allowed to warm to r.t. overnight. TLC (heptane/EtOAc 1:1) showed full conversion, and afterwards the remaining $\mathrm{HF}$ was quenched by addition of methoxytrimethylsilane $(0.96 \mathrm{~mL}, 6.96 \mathrm{mmol})$ followed by stirring for $1 \mathrm{~h}$. The mixture was diluted with $\mathrm{CH}_{2} \mathrm{Cl}_{2}$ and washed with sat. aq. $\mathrm{NaHCO}_{3}$ and water. The organic phase was dried over $\mathrm{Na}_{2} \mathrm{SO}_{4}$, filtered, and the solvent removed in vacuo. The crude mixture was purified by flash column chromatography (heptane/EtOAc 4:3) yielding the product 8 as a white amorphous solid $(0.073 \mathrm{~g}, 91 \%) . R_{\mathrm{f}}=0.24$ (heptane/EtOAc $\left.1: 1\right) .[\alpha]$ $\mathrm{D}^{25}=-18.8\left(\mathrm{c} 0.47, \mathrm{CHCl}_{3}\right) .{ }^{1} \mathrm{H}$ NMR $\left(400 \mathrm{MHz} \mathrm{CDCl}_{3}\right): \delta=7.47-7.45(\mathrm{~m}$, $2 \mathrm{H}), 7.32-7.24(\mathrm{~m}, 5 \mathrm{H}), 6.89-6.83(\mathrm{~m}, 2 \mathrm{H}), 4.83\left(\mathrm{dd}, J_{1,2}=9.8 \mathrm{~Hz}, J_{2,3}=\right.$
$9.0 \mathrm{~Hz}, 1 \mathrm{H}, \mathrm{H} 2), 4.69$ (d, J = $11.5 \mathrm{~Hz}, 1 \mathrm{H}, \mathrm{PMB}$ ), 4.60 (d, $J_{1,2}=9.8 \mathrm{~Hz}$, $1 \mathrm{H}, \mathrm{H} 1), 4.58$ (d, J=11.4 Hz, 1H, PMB), 4.01 (dd, J5,5 = $11.5 \mathrm{~Hz}, J_{5,4}=$ $5.2 \mathrm{~Hz}, 1 \mathrm{H}, \mathrm{H} 5 \mathrm{eq}$ ), 3.80 (s, 3H, OMe), 3.75 (t, J=8.9 Hz, 1H, H3), 3.53 (ddd, $\left.J_{4,5^{\prime}}=10.2 \mathrm{~Hz}, J_{3,4}=8.9 \mathrm{~Hz}, J_{4,5}=5.2 \mathrm{~Hz}, 1 \mathrm{H}, \mathrm{H} 4\right), 3.22$ (dd, J5, $J^{\prime}=$ $11.5 \mathrm{~Hz}, J_{5^{\prime}, 4}=10.3 \mathrm{~Hz}, 1 \mathrm{H}, \mathrm{H}^{\prime}$ ax), 2.94-2.76 (m, 2H), 2.69-2.56 (m, $2 \mathrm{H}), 2.20(\mathrm{~s}, 3 \mathrm{H}) .{ }^{13} \mathrm{C}$ NMR $\left(101 \mathrm{MHz}, \mathrm{CDCl}_{3}\right): \delta=207.6,172.1,159.6$, 132.9, 132.5 (×2), 130.2, 129.7 (×2), $129.1(\times 2), 128.0,114.1(\times 2), 86.5$ (C1), 76.6 (C4), 76.4 (C3), 73.2 (PMB), 72.8 (C2), 67.9 (C5), 55.4 (OMe), 38.5, 30.0, 28.4. HRMS: calcd. for $\mathrm{C}_{24} \mathrm{H}_{28} \mathrm{O}_{7} \mathrm{SNa}[\mathrm{M}+\mathrm{Na}]^{+} 483.1447$; found 483.1458 .

Phenyl 3-O-benzoyl-2-O-levulinoyl-1-thio- $\beta$-D-xylopyranoside (6): To alcohol 8 (0.893 g, $1.94 \mathrm{mmol})$ dissolved in dry pyridine $(4.0 \mathrm{~mL})$ was added $\mathrm{BzCl}(0.34 \mathrm{~mL}, 2.91 \mathrm{mmol})$ and the solution was left to stir at r.t. After $17 \mathrm{~h}$ TLC (heptane/EtOAc 1:1) showed full conversion. DMAPA $(0.37 \mathrm{~mL}, 2.91 \mathrm{mmol})$ was added to quench excess $\mathrm{BzCl}$. After stirring for $1 \mathrm{~h}, \mathrm{CH}_{2} \mathrm{Cl}_{2}$ was added and the mixture was washed with $1 \mathrm{M} \mathrm{HCl}$ and brine, dried over $\mathrm{MgSO}_{4}$, filtered, and conc. in vacuo thereby providing the crude product as a yellow oil $(1.0053 \mathrm{~g}, 1.78 \mathrm{mmol})$. This material was directly dissolved in a $10: 1$ mixture of $\mathrm{CH}_{2} \mathrm{Cl}_{2} / \mathrm{H}_{2} \mathrm{O}(11 \mathrm{~mL})$ and $\mathrm{DDQ}$ $(0.566 \mathrm{~g}, 2.49 \mathrm{mmol})$ was added. The reaction was stirred vigorously at r.t. in the dark overnight. TLC (heptane/EtOAc 1:1) showed full conversion and the mixture was filtered through a thick pad of Celite. The filtrate was washed with sat. aq. $\mathrm{NaHCO}_{3}$, brine, dried over $\mathrm{MgSO}_{4}$, filtered, and conc. in vacuo. The residue was purified by flash column chromatography (hexane/EtOAc 1:1) to obtain alcohol 6 as a white solid $(0.696 \mathrm{~g}, 81 \%) . R_{\mathrm{f}}=0.42$ (hexane/EtOAc 2:1). $[\alpha]_{\mathrm{D}}^{25}=+16.1$ (c 0.6, $\left.\mathrm{CHCl}_{3}\right) .{ }^{1} \mathrm{H}$ NMR $\left(400 \mathrm{MHz}, \mathrm{CDCl}_{3}\right): \delta=8.08-8.05(\mathrm{~m}, 2 \mathrm{H}), 7.62-7.58(\mathrm{~m}$, $1 \mathrm{H}), 7.53-7.51(\mathrm{~m}, 2 \mathrm{H}), 7.48-7.45(\mathrm{~m}, 2 \mathrm{H}), 7.36-7.31(\mathrm{~m}, 3 \mathrm{H})$, 5.19-5.15 (m, 2H, H2, H3), 4.96-4.91 (m, 1H, H1), 4.37 (dd, J5eq,5ax $=11.9 \mathrm{~Hz}, J_{5 \text { eq, } 4}$ $=4.4 \mathrm{~Hz}, 1 \mathrm{H}, \mathrm{H} 5 \mathrm{eq}), 3.93-3.88(\mathrm{~m}, 1 \mathrm{H}, \mathrm{H} 4), 3.54\left(\mathrm{dd}, J_{5 \mathrm{ax}, 5 \mathrm{eq}}=11.9 \mathrm{~Hz}\right.$, $\left.J_{5 a x, 4}=7.9 \mathrm{~Hz}, 1 \mathrm{H}, \mathrm{H} 5 \mathrm{ax}\right), 3.03(\mathrm{bs}, 1 \mathrm{H}, \mathrm{OH}), 2.71-2.67(\mathrm{~m}, 2 \mathrm{H}), 2.64-$ $2.50(\mathrm{~m}, 2 \mathrm{H}), 2.09(\mathrm{~s}, 3 \mathrm{H}) .{ }^{13} \mathrm{C}$ NMR $\left(101 \mathrm{MHz} \mathrm{CDCl}_{3}\right): \delta=206.0,171.4$, 167.0, 133.9, 133.0, $132.7(\times 2), 130.3(\times 2), 129.2(\times 2), 129.0,128.7(\times 2)$, 128.2, 86.5 (C1), 75.8, 69.8 (C2, C3), 68.3 (C4), 67.5 (C5), 38.0, 29.8, 28.1. HRMS: calcd. for $\mathrm{C}_{23} \mathrm{H}_{24} \mathrm{O}_{7} \mathrm{SNa}[\mathrm{M}+\mathrm{Na}]^{+}$467.1134; found 467.1146.

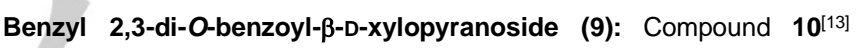
$(0.200 \mathrm{~g}, 0.35 \mathrm{mmol})$ and benzyl alcohol $(0.044 \mathrm{ml}, 0.42 \mathrm{mmol})$ were mixed in the reaction flask and dried overnight on the vacuum line. The reactants were dissolved in $\mathrm{CH}_{2} \mathrm{Cl}_{2}(6 \mathrm{~mL})$, cooled to $-40{ }^{\circ} \mathrm{C}$ followed by addition of NIS $(0.094 \mathrm{mg}, 0.42 \mathrm{mmol})$ and triflic acid $(9 \mu \mathrm{l}, 0.11 \mathrm{mmol})$ to the stirred mixture. Full conversion of the starting material was observed via TLC analysis after 20 minutes and the reaction was neutralized with $\mathrm{Et}_{3} \mathrm{~N}(0.145 \mathrm{~mL}, 1.05 \mathrm{mmol})$. The resulting mixture was stirred with $1 \mathrm{M}$ $\mathrm{Na}_{2} \mathrm{~S}_{2} \mathrm{O}_{3}(6 \mathrm{~mL})$ until the yellow color disappeared. The organic phase was diluted with $\mathrm{CH}_{2} \mathrm{Cl}_{2}$, washed with brine, dried over $\mathrm{Na}_{2} \mathrm{SO}_{4}$, filtered, concentrated and purified with flash chromatography (heptane/ethyl acetate 7:3) yielding benzyl 2,3-di-O-benzoyl-4-O-( $p$-methoxy)benzyl- $\beta$-Dxylopyranoside $(0.155 \mathrm{~g}, 78 \%)$ as a colorless oil. ${ }^{1} \mathrm{H} \mathrm{NMR}(400 \mathrm{MHz}$, $\left.\mathrm{CDCl}_{3}\right): \delta=7.96-7.93(\mathrm{~m}, 4 \mathrm{H}), 7.55-7.50(\mathrm{~m}, 2 \mathrm{H}), 7.39-7.35(\mathrm{~m}, 5 \mathrm{H})$, 7.25-7.21 (m, 4H), 7.16-7.14 (m, 2H) 6.76-6.72 (m, 2H), $5.56(\mathrm{t}, J=8.1$ $\mathrm{Hz}, 1 \mathrm{H}, \mathrm{H} 3$ ), 5.35 (dd, $\left.J_{2,3}=8.3 \mathrm{~Hz}, J_{1,2}=6.5 \mathrm{~Hz}, 1 \mathrm{H}, \mathrm{H} 2\right), 4.87$ (d, J= $12.3 \mathrm{~Hz}, 1 \mathrm{H}, \mathrm{Bn}), 4.74$ (d, J1,2 $=6.5 \mathrm{~Hz}, 1 \mathrm{H}, \mathrm{H} 1), 4.63(\mathrm{~d}, J=12.3 \mathrm{~Hz}, 1 \mathrm{H}$, Bn), 4.57 (d, $J=11.8 \mathrm{~Hz}, 1 \mathrm{H}, \mathrm{PMB}), 4.54$ (d, $J=11.8 \mathrm{~Hz}, 1 \mathrm{H}, \mathrm{PMB}), 4.14$ (dd, J5eq,5ax $\left.=11.9 \mathrm{~Hz}, J_{5 \text { eq }, 4}=4.6 \mathrm{~Hz}, 1 \mathrm{H}, \mathrm{H} 5_{\text {eq }}\right), 3.83-3.77(\mathrm{~m}, 1 \mathrm{H}, \mathrm{H} 4)$, 3.76 (s, 3H, OMe), 3.51 (dd, J5ax,5eq $=11.9 \mathrm{~Hz}, J_{5 a x, 4}=8.5 \mathrm{~Hz}, 1 \mathrm{H}, \mathrm{H} 5 \mathrm{ax}$ ). ${ }^{13} \mathrm{C}$ NMR $\left(101 \mathrm{MHz}, \mathrm{CDCl}_{3}\right): \delta=165.7,165.4,159.4,141.1,137.1,133.2$, $130.0,129.9,129.7,129.6,129.6,129.5,128.6,128.4,128.4,128.4$, 127.9, 127.8, 127.7, 127.1, 113.9, 99.4 (C1), 74.0 (C4), 72.6 (C3), 72.4 (PMB), $71.1(\mathrm{C} 2), 70.4(\mathrm{Bn}), 63.1(\mathrm{C} 5), 55.3(\mathrm{OMe})$. The above glycoside $(0.155 \mathrm{~g}, 0.27 \mathrm{mmol})$ was dissolved in $\mathrm{CH}_{2} \mathrm{Cl}_{2} / \mathrm{H}_{2} \mathrm{O}$ 9:1 $(3 \mathrm{~mL})$ and DDQ $(0.093 \mathrm{~g}, 0.41 \mathrm{mmol})$ was added. The reaction was vigorously stirred for $4 \mathrm{~h}$ at r.t. and the remaining DDQ was quenched using a buffer solution composed of ascorbic acid (0.7\%, $0.072 \mathrm{~g}, 0.41 \mathrm{mmol})$, citric acid (1.5\%) and sodium hydroxide (1\%). The mixture was diluted with $\mathrm{CH}_{2} \mathrm{Cl}_{2}$ and washed with sat. aq. $\mathrm{NaHCO}_{3}$ and water. The organic phase was dried with $\mathrm{Na}_{2} \mathrm{SO}_{4}$, filtered and conc. in vacuo affording alcohol $9(0.113 \mathrm{~g}$, 
93\%) as a white amorphous solid after purification by column chromatography (heptane/EtOAc 7:3). ${ }^{1} \mathrm{H}$ NMR $\left(400 \mathrm{MHz}, \mathrm{CDCl}_{3}\right): \delta=$ 7.99-7.97 (m, 4H), 7.59-7.52 (m, 2H), 7.45-7.35 (m, 4H), 7.30-7.23 (m, $5 \mathrm{H}$ ), $5.44\left(\mathrm{dd}, J_{2,3}=7.8 \mathrm{~Hz}, J_{1,2}=6.0 \mathrm{~Hz}, 1 \mathrm{H}, \mathrm{H} 2\right), 5.27(\mathrm{t}, J=7.5 \mathrm{~Hz}, 1 \mathrm{H}$, $\mathrm{H} 3), 4.90(\mathrm{~d}, J=12.2 \mathrm{~Hz}, 1 \mathrm{H}, \mathrm{Bn}), 4.79\left(\mathrm{~d}, J_{1,2}=6.0 \mathrm{~Hz}, 1 \mathrm{H}, \mathrm{H1}\right.$ ), $4.66(\mathrm{~d}$, $J=12.2 \mathrm{~Hz}, 1 \mathrm{H}, \mathrm{Bn}), 4.28\left(\mathrm{dd}, J_{5 e q, 5 a x}=12.0 \mathrm{~Hz}, J_{5 \text { eq }, 4}=4.4 \mathrm{~Hz}, 1 \mathrm{H}\right.$, H5 eq), 4.03 (td, $J=7.6 \mathrm{~Hz}, J_{4,5 \text { eq }} 4.5 \mathrm{~Hz}, 1 \mathrm{H}, \mathrm{H} 4$ ), 3.55 (dd, J5ax,5eq $=12.0$ $\mathrm{Hz}, J_{5 a x, 4}=7.7 \mathrm{~Hz}, 1 \mathrm{H}, \mathrm{H} 5$ ax $) .{ }^{13} \mathrm{C} \mathrm{NMR}\left(101 \mathrm{MHz}, \mathrm{CDCl}_{3}\right): \delta=167.2$, $165.3,137.0,133.7,133.5,130.1,130.0,129.4,129.0,128.6,128.5$, 128.5, 128.0, 99.1 (C1), 75.4 (C3), 70.5 (C2), 70.4 (Bn), 68.7 (C4), 64.6 (C5). HRMS: calcd. for $\mathrm{C}_{26} \mathrm{H}_{24} \mathrm{O}_{7} \mathrm{Na}[\mathrm{M}+\mathrm{Na}]^{+} 471.1414$; found 471.1450 .

Glycosylation with Thiophenyl Donor (General Procedure A): Crushed molecular sieves ( $3 \AA$ ) was added to a 2-neck Schlenk flask, where the middle neck was fitted with a glass stopper and the other with a septum. The flask was then placed under vacuum and heated. Afterwards an atm. of $\mathrm{N}_{2}$ was applied. The donor (1.0 equiv.) dissolved in dry $\mathrm{CH}_{2} \mathrm{Cl}_{2}(\mathrm{c}=0.12 \mathrm{M})$ was added to the flask together with AgOTf $(2.0$ equiv.) dissolved in dry toluene $(\mathrm{c}=0.36 \mathrm{M})$. Stirring of the reaction was initiated and the glass stopper exchanged for a thermometer under $\mathrm{N}_{2}$ pressure, and the solution cooled to $-65{ }^{\circ} \mathrm{C}$. $p$-Nitrobenzenesulfenyl chloride (1.0 equiv.) was dissolved in dry $\mathrm{CH}_{2} \mathrm{Cl}_{2}(\mathrm{c}=0.72 \mathrm{M})$ and slowly added as to not raise the temperature above $-60^{\circ} \mathrm{C}$. The mixture is left to stir for approximately $10 \mathrm{~min}$ until the activation was completed. The acceptor ( 0.9 equiv.) was dissolved in dry $\mathrm{CH}_{2} \mathrm{Cl}_{2}(\mathrm{c}=0.65 \mathrm{M})$ and added quickly. The temperature was kept between $-55^{\circ} \mathrm{C}$ and $-50{ }^{\circ} \mathrm{C}$ for the reaction time indicated. Afterwards the mixture was allowed to warm to $15{ }^{\circ} \mathrm{C}$ over $10 \mathrm{~min}$ at which point $\mathrm{Et}_{3} \mathrm{~N}$ (3.0 equiv.) was added. The solution was filtered through a pad of Celite and conc. in vacuo. The residue was purified by flash column chromatography to afford the product.

Glycosylation with Glucuronic Acid Donor (General Procedure B): Crushed molecular sieves $(3 \AA)$ was added to a 2-neck Schlenk flask, where the middle neck was fitted with a glass stopper and the other with a septum. The flask was placed under vacuum and heated. Afterwards an atm. of $\mathrm{N}_{2}$ was applied. The donor (4.0 equiv.) dissolved in dry $\mathrm{CH}_{2} \mathrm{Cl}_{2}$ ( $\mathrm{C}=0.2 \mathrm{M}$ ) was added to the flask. Stirring of the reaction was initiated and the glass stopper exchanged for a thermometer under $\mathrm{N}_{2}$ pressure, and the solution cooled to $-30^{\circ} \mathrm{C}$. $\mathrm{Br}_{2}\left(1 \mathrm{M}\right.$ in $\left.\mathrm{CH}_{2} \mathrm{Cl}_{2}\right)$ was slowly added until a yellow color persisted, and then the mixture was left to stir for 10 min. Acceptor (1 equiv.) dissolved in dry $\mathrm{CH}_{2} \mathrm{Cl}_{2}(\mathrm{c}=0.2 \mathrm{M})$ was added alongside dry $\mathrm{Et}_{2} \mathrm{O}$ (23 vol.\%). $\mathrm{AgClO}_{4}$ (4.8 equiv.) dissolved in dry toluene $(\mathrm{c}=3.0 \mathrm{M})$ was added. The reaction was stirred at $-30^{\circ} \mathrm{C}$ for $2 \mathrm{~h}$, at which point $\mathrm{Et}_{3} \mathrm{~N}$ (5.0 equiv.) was added. The solution was allowed to warm to r.t., filtered through a pad of Celite and conc. in vacuo. The residue was purified by flash column chromatography to afford the product.

Deprotection of methyl ester and benzoyl groups (General Procedure $\mathrm{C}$ ): The fully protected hexasaccharide (1.0 equiv.) was dissolved in THF $(\mathrm{C}=0.013 \mathrm{M})$ and the solution cooled to $0{ }^{\circ} \mathrm{C}$ under an atm. of $\mathrm{N}_{2}$. A solution of $1 \mathrm{M}$ aq. $\mathrm{LiOH}$ (50 equiv.) and $\mathrm{H}_{2} \mathrm{O}_{2}$ (100 equiv.) was added and the reaction left to stir for the reaction time indicated. The mixture was conc. in vacuo after which the intermediate was re-dissolved in $\mathrm{MeOH}(\mathrm{c}=0.016 \mathrm{M})$ and $3 \mathrm{M} \mathrm{NaOH}$ was added until the solution was basic and left to stir overnight. At completion of the reaction, the solution was neutralized using $0.1 \mathrm{M} \mathrm{HCl}$ and then conc. in vacuo. The resulting residue was purified through a SepPak $\mathrm{C} 18$ Classic cartridge (eluent $\mathrm{H}_{2} \mathrm{O}$ $-\mathrm{H}_{2} \mathrm{O}$ and $40 \%$ acetonitrile).

Phenyl 2,3,4-tri-O-benzoyl- $\beta$-D-xylopyranosyl-(1 $\rightarrow 4)-3-O$-benzoyl-2O-levulinoyl-1-thio- $\beta$-D-xylopyranoside (11): General procedure A: Crushed molecular sieves $(1.004 \mathrm{~g})$. Donor $3(0.475 \mathrm{~g}, 0.86 \mathrm{mmol})$. AgOTf $(0.440 \mathrm{~g}, 1.71 \mathrm{mmol})$. p-Nitrobenzenesulfenyl chloride $(0.178 \mathrm{~g}$, $0.94 \mathrm{mmol})$. Acceptor 6 (0.034 g, $0.77 \mathrm{mmol})$. Reaction time $23 \mathrm{~min}$. Et $3 \mathrm{~N}$ $(0.36 \mathrm{~mL}, 2.58 \mathrm{mmol})$. Eluent for flash column chromatography heptane/toluene/EtOAc 6:2:2. The product was obtained as light yellow crystals $(0.611 \mathrm{~g}, 89 \%) . R_{\mathrm{f}}=0.54$ (hexane/toluene/EtOAc 3:1:2). $[\alpha]_{5}^{25}=-$ 43.6 (c $\left.0.38, \mathrm{CHCl}_{3}\right)$. ${ }^{1} \mathrm{H}$ NMR $\left(400 \mathrm{MHz}, \mathrm{CDCl}_{3}\right): \delta=8.06-8.04(\mathrm{~m}, 2 \mathrm{H})$, 7.97-7.91 (m, 6H), 7.58-7.28 (m, 17H), 5.64 (t, $\left.J=6.6 \mathrm{~Hz}, 1 \mathrm{H}, \mathrm{H}^{\mathrm{B}}\right)$, $5.50\left(\mathrm{t}, J=8.2 \mathrm{~Hz}, 1 \mathrm{H}, \mathrm{H}^{\mathrm{A}}\right), 5.22\left(\mathrm{dd}, J_{2 \mathrm{~B}, 3 \mathrm{~B}}=6.6 \mathrm{~Hz}, J_{1 \mathrm{~B}, 2 \mathrm{~B}}=4.9 \mathrm{~Hz}\right.$, $\left.1 \mathrm{H}, \mathrm{H} 2^{\mathrm{B}}\right), 5.11-5.04\left(\mathrm{~m}, 2 \mathrm{H}, \mathrm{H} 2^{\mathrm{A}}, \mathrm{H} 4^{\mathrm{B}}\right), 4.91\left(\mathrm{~d}, \mathrm{~J}_{1 \mathrm{~B}, 2 \mathrm{~B}}=4.8 \mathrm{~Hz}, 1 \mathrm{H}, \mathrm{H} 1^{\mathrm{B}}\right)$, $4.83\left(\mathrm{~d}, J_{1 \mathrm{~A}, 2 \mathrm{~A}}=8.6 \mathrm{~Hz}, 1 \mathrm{H}, \mathrm{H}^{\mathrm{A}}\right), 4.19\left(\mathrm{dd}, \mathrm{J}_{5 \mathrm{~A}, 5 \mathrm{~A}^{\prime}}=12.0 \mathrm{~Hz}, J_{5 \mathrm{~A}, 4 \mathrm{~A}=4.9}\right.$ $\left.\mathrm{Hz}, 1 \mathrm{H}, \mathrm{H} 5^{\mathrm{A}}\right), 4.08-4.00\left(\mathrm{~m}, 2 \mathrm{H}, \mathrm{H} 4^{\mathrm{A}}, \mathrm{H} 5^{\mathrm{B}}\right), 3.48-3.40\left(\mathrm{~m}, 2 \mathrm{H}, \mathrm{H}^{5 \mathrm{~A}}\right.$, $\left.\mathrm{H}^{\mathrm{B}^{\prime}}\right), 2.64-2.46(\mathrm{~m}, 4 \mathrm{H}), 2.08(\mathrm{~s}, 3 \mathrm{H}) .{ }^{13} \mathrm{C} \mathrm{NMR}\left(101 \mathrm{MHz}, \mathrm{CDCl}_{3}\right): \delta=$ 205.9, 171.4, 165.6, 165.5, 165.3, 165.1, 133.5, 133.5, 133.5, 132.8, $132.5,130.0,130.0,129.9,129.9,129.5,129.3,129.1,129.0,128.6$, 128.6, 128.5, 128.5, 128.3, 99.8 $\left(\mathrm{C}^{\mathrm{B}}\right), 86.5\left(\mathrm{C} 1^{\mathrm{A}}\right), 75.3\left(\mathrm{C} 4^{\mathrm{A}}\right), 73.5$ $\left(\mathrm{C} 3^{\mathrm{A}}\right), 70.4\left(\mathrm{C} 2^{\mathrm{A}}\right), 70.2\left(\mathrm{C} 2^{\mathrm{B}}\right), 69.6\left(\mathrm{C} 3^{\mathrm{B}}\right), 68.6\left(\mathrm{C} 4^{\mathrm{B}}\right), 66.1\left(\mathrm{C} 5^{\mathrm{A}}\right), 60.9$ (C5 $\left.{ }^{B}\right), 37.9,29.8$, 28.1. HRMS: calcd. for $\mathrm{C}_{49} \mathrm{H}_{44} \mathrm{O}_{14} \mathrm{SNa}\left[\mathrm{M}+\mathrm{Na}^{+}\right.$ 911.2343; found 911.2362 .

Phenyl 2,3,4-tri-O-benzoyl- $\beta$-D-xylopyranosyl-(1 $\rightarrow 4)$-3-O-benzoyl-2O-levulinoyl- $\beta$-D-xylopyranosyl-( $1 \rightarrow 4)-2,3-d i-O$-benzoyl-1-thio- $\beta$-Dxylopyranoside (12): General procedure A: Crushed molecular sieves (0.372 g). Donor 11 (1.131 g, $1.27 \mathrm{mmol})$. AgOTf $(0.654 \mathrm{~g}, 2.55 \mathrm{mmol})$. $p$-Nitrobenzenesulfenyl chloride $(0.240 \mathrm{~g}, 1.27 \mathrm{mmol})$. Acceptor 4 $(0.4158 \mathrm{~g}, 1.14 \mathrm{mmol})$. Reaction time $85 \mathrm{~min}$. $\mathrm{Et}_{3} \mathrm{~N}(0.53 \mathrm{~mL}, 3.81 \mathrm{mmol})$. Eluent for flash column chromatography hexane/toluene/EtOAc 2:1:1. The product was obtained as a white crystalline solid $(0.768 \mathrm{~g}, 68 \%) . R_{\mathrm{f}}$ $=0.46$ (hexane/toluene/EtOAc 3:1:2). $[\alpha]^{25}=-43.3$ (c 0.24, $\left.\mathrm{CHCl}_{3}\right) .{ }^{1} \mathrm{H}$ NMR $\left(400 \mathrm{MHz}, \mathrm{CDCl}_{3}\right): \delta=8.00-7.88(\mathrm{~m}, 12 \mathrm{H}), 7.57-7.28(\mathrm{~m}, 23 \mathrm{H})$, 5.62-5.56 (m, 2H, H3 $\left.{ }^{\mathrm{A}}, \mathrm{H}^{\mathrm{C}}\right), 5.35\left(\mathrm{t}, J=8.4 \mathrm{~Hz}, 1 \mathrm{H}, \mathrm{H} 3^{\mathrm{B}}\right), 5.32\left(\mathrm{t}, J_{1 \mathrm{~A}, 2 \mathrm{~A}}\right.$

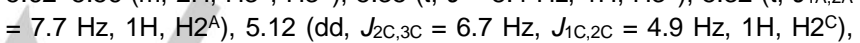
$5.06\left(\mathrm{~d}, \mathrm{~J}_{1 \mathrm{~A}, 2 \mathrm{~A}}=7.8 \mathrm{~Hz}, 1 \mathrm{H}, \mathrm{H} 1^{\mathrm{A}}\right), 5.06-5.02\left(\mathrm{~m}, 1 \mathrm{H}, \mathrm{H}^{\mathrm{C}}\right), 4.90\left(\mathrm{dd}, \mathrm{J}_{2 \mathrm{~B}, 3 \mathrm{~B}}\right.$ $\left.=8.5 \mathrm{~Hz}, J_{1 \mathrm{~B}, 2 \mathrm{~B}}=6.7 \mathrm{~Hz}, 1 \mathrm{H}, \mathrm{H} 2^{\mathrm{B}}\right), 4.68\left(\mathrm{~d}, \mathrm{~J}_{1 \mathrm{C}, 2 \mathrm{C}}=4.8 \mathrm{~Hz}, 1 \mathrm{H}, \mathrm{H}^{\mathrm{C}}\right)$, $4.59\left(\mathrm{~d}, J_{1 \mathrm{~B}, 2 \mathrm{~B}}=6.7 \mathrm{~Hz}, 1 \mathrm{H}, \mathrm{H}^{\mathrm{B}}{ }^{\mathrm{B}}\right), 4.36\left(\mathrm{dd}, J_{5 \text { Aeq, } 5 \mathrm{Aax}}=12.2 \mathrm{~Hz}, J_{5 \text { Aeq, } 4 \mathrm{~A}}=\right.$ 4.6 Hz, $\left.1 \mathrm{H}, \mathrm{H} 5^{\mathrm{A}} \mathrm{eq}\right), 4.01-3.95\left(\mathrm{~m}, 2 \mathrm{H}, \mathrm{H}^{\mathrm{A}}, \mathrm{H} 5^{\mathrm{C}}\right), 3.76(\mathrm{td}, J=8.5 \mathrm{~Hz}$, $\left.J_{4 \mathrm{~B}, 5 \mathrm{~B} \text { eq }}=5.0 \mathrm{~Hz}, 1 \mathrm{H}, \mathrm{H} 4^{\mathrm{B}}\right), 3.63\left(\mathrm{dd}, J_{5 \mathrm{Aax}, 5 \mathrm{Aeq}}=12.1 \mathrm{~Hz}, J_{5 \mathrm{Aax}, 4 \mathrm{~A}}=8.3\right.$ $\left.\mathrm{Hz}, 1 \mathrm{H}, \mathrm{H}^{\mathrm{A}} \mathrm{ax}\right), 3.52\left(\mathrm{dd}, J_{5 \mathrm{Beq}, 5 \mathrm{Bax}}=12.2 \mathrm{~Hz}, J_{5 \mathrm{Beq}, 4 \mathrm{~B}}=4.9 \mathrm{~Hz}, 1 \mathrm{H}\right.$, $\mathrm{H}^{\mathrm{B}}{ }_{\text {eq }}$ ), 3.35 (dd, $J=12.3,6.2 \mathrm{~Hz}, 1 \mathrm{H}, \mathrm{H} 5^{\mathrm{C}^{\prime}}$ ), 3.09 (dd, $J_{5 \mathrm{Bax}, 5 \mathrm{Beq}}=12.2$ $\left.\mathrm{Hz}, J_{5 \mathrm{Bax}, 5 \mathrm{~B} 4 \mathrm{~A}}=9.0 \mathrm{~Hz}, 1 \mathrm{H}, \mathrm{H}^{\mathrm{B}} \mathrm{ax}\right), 2.65-2.36(\mathrm{~m}, 4 \mathrm{H}), 2.07(\mathrm{~s}, 3 \mathrm{H}) .{ }^{13} \mathrm{C}$ NMR $\left(101 \mathrm{MHz}, \mathrm{CDCl}_{3}\right): \delta=206.0,171.3,165.6,165.5(\times 2), 165.4$, $165.4,165.3,165.0,133.6,133.6,133.5,133.5,133.3,133.2,133.0$, $132.7,130.1,130.0,130.0,129.9,129.9,129.9,129.7,129.5,129.3$, 129.2, 129.1, 129.0, 128.6, 128.6, 128.6, 128.5, 128.5, 128.4, 128.1, $100.8\left(C 1^{B}\right), 99.5\left(C 1^{\mathrm{C}}\right), 86.7\left(C 1^{\mathrm{A}}\right), 75.5\left(\mathrm{C} 4^{\mathrm{A}}\right), 75.0\left(\mathrm{C} 4^{\mathrm{B}}\right), 72.8\left(\mathrm{C} 3^{\mathrm{A}}\right)$, $72.5\left(\mathrm{C}^{\mathrm{B}}\right), 71.6\left(\mathrm{C} 2^{\mathrm{B}}\right), 70.5\left(\mathrm{C} 2^{\mathrm{A}}\right), 70.1\left(\mathrm{C} 2^{\mathrm{C}}\right), 69.6\left(\mathrm{C} 3^{\mathrm{C}}\right), 68.6\left(\mathrm{C} 4^{\mathrm{C}}\right)$, $65.6\left(\mathrm{C}^{\mathrm{A}}\right), 62.4\left(\mathrm{C} 5^{\mathrm{B}}\right), 60.9$ (C5 $), 37.8,29.8,27.9$. HRMS: calcd. for $\mathrm{C}_{68} \mathrm{H}_{60} \mathrm{O}_{20} \mathrm{SNa}[\mathrm{M}+\mathrm{Na}]^{+} 1251.3290$; found 1251.3311 .

Phenyl 2,3,4-tri-O-benzoyl- $\beta$-D-xylopyranosyl-(1 $\rightarrow 4)-3-O-$-benzoyl-2$O$-levulinoyl- $\beta$-D-xylopyranosyl-(1 $\rightarrow 4)-2,3-d i-O$-benzoyl- $\beta$-Dxylopyranosyl-(1 $\rightarrow 4)-2,3-d i-O$-benzoyl-1-thio- $\beta$-D-xylopyranoside (13): General procedure A: Crushed molecular sieves (1.050 g). Donor $12(0.550 \mathrm{~g}, 0.45 \mathrm{mmol})$. AgOTf $(0.230 \mathrm{~g}, 0.90 \mathrm{mmol})$. $p$ Nitrobenzenesulfenyl chloride $(0.102 \mathrm{~g}, 0.54 \mathrm{mmol})$. Acceptor $4(0.181 \mathrm{~g}$, $0.40 \mathrm{mmol})$. Reaction time $60 \mathrm{~min}$. Et $3 \mathrm{~N}(0.09 \mathrm{~mL}, 1.35 \mathrm{mmol})$. Eluent for flash column chromatography hexane/toluene/EtOAc 2:1:1. The product was obtained as a white crystalline solid $(0.500 \mathrm{~g}, 79 \%) . R_{\mathrm{f}}=0.38$ (hexane/toluene/EtOAc 3:1:2). $[\alpha]_{\mathrm{D}}^{25}=-42.1$ (c $\left.0.38, \mathrm{CHCl}_{3}\right) .{ }^{1} \mathrm{H}$ NMR $\left(400 \mathrm{MHz}, \mathrm{CDCl}_{3}\right): \delta=8.01-7.86(\mathrm{~m}, 16 \mathrm{H}), 7.57-7.50(\mathrm{~m}, 6 \mathrm{H}), 7.45-7.25$ $(\mathrm{m}, 22 \mathrm{H}), 7.18-7.13(\mathrm{~m}, 1 \mathrm{H}), 5.63\left(\mathrm{t}, J=7.9 \mathrm{~Hz}, 1 \mathrm{H}, \mathrm{H}^{\mathrm{A}}\right), 5.57(\mathrm{t}, J=6.7$ $\left.\mathrm{Hz}, 1 \mathrm{H}, \mathrm{H} 3^{\mathrm{D}}\right), 5.46\left(\mathrm{t}, J=7.7 \mathrm{~Hz}, 1 \mathrm{H}, \mathrm{H} 3^{\mathrm{B}}\right), 5.33-5.27\left(\mathrm{~m}, 2 \mathrm{H}, \mathrm{H}^{\mathrm{A}}, \mathrm{H} 3^{\mathrm{C}}\right)$, $5.15\left(\mathrm{dd}, \mathrm{J}_{2 \mathrm{~B}, 3 \mathrm{~B}}=7.9 \mathrm{~Hz}, J_{1 \mathrm{~B}, 2 \mathrm{~B}}=6.0 \mathrm{~Hz}, 1 \mathrm{H}, \mathrm{H} 2^{\mathrm{B}}\right), 5.11\left(\mathrm{dd}, \mathrm{J}_{2 \mathrm{D}, 3 \mathrm{D}}=6.4\right.$ $\left.\mathrm{Hz}, J_{1 \mathrm{D}, 2 \mathrm{D}}=4.7 \mathrm{~Hz}, 1 \mathrm{H}, \mathrm{H} 2^{\mathrm{D}}\right), 5.03\left(\mathrm{td}, J=6.3,4.1 \mathrm{~Hz}, 1 \mathrm{H}, \mathrm{H} 4^{\mathrm{D}}\right), 4.98(\mathrm{~d}$, $J_{1 \mathrm{~A}, 2 \mathrm{~A}}=8.0 \mathrm{~Hz}, 1 \mathrm{H}, \mathrm{H}^{\mathrm{A}}{ }^{\mathrm{A}}, 4.83\left(\mathrm{dd}, J=8.6 \mathrm{~Hz}, J_{1 \mathrm{C}, 2 \mathrm{C}}=6.8 \mathrm{~Hz}, 1 \mathrm{H}, \mathrm{H} 2^{\mathrm{C}}\right)$, $4.78\left(\mathrm{~d}, J_{1 \mathrm{~B}, 2 \mathrm{~B}}=6.1 \mathrm{~Hz}, 1 \mathrm{H}, \mathrm{H} 1^{\mathrm{B}}\right), 4.66\left(\mathrm{~d}, \mathrm{~J}_{1 \mathrm{D}, 2 \mathrm{D}}=4.9 \mathrm{~Hz}, 1 \mathrm{H}, \mathrm{H} 1^{\mathrm{D}}\right), 4.35$ $\left(\mathrm{d}, J_{1 \mathrm{C}, 2 \mathrm{C}}=6.8 \mathrm{~Hz}, 1 \mathrm{H}, \mathrm{H} 1^{\mathrm{C}}\right), 4.18\left(\mathrm{dd}, J_{5 \mathrm{~A}, 5^{\prime} \mathrm{A}}=12.1 \mathrm{~Hz}, J_{5 \mathrm{~A}, 4 \mathrm{~A}}=4.7 \mathrm{~Hz}\right.$, $\left.1 \mathrm{H}, \mathrm{H}^{\mathrm{A}}{ }_{\mathrm{eq}}\right), 4.03\left(\mathrm{td}, J=8.2 \mathrm{~Hz}, J_{4 \mathrm{~A}, 5 \mathrm{~A}}=4.8 \mathrm{~Hz}, 1 \mathrm{H}, \mathrm{H} 4^{\mathrm{A}}\right), 3.97(\mathrm{dd}$, $\left.J_{5 \text { Deq, } 5 \mathrm{Dax}}=12.4 \mathrm{~Hz}, J_{5 \mathrm{Deq}, 4 \mathrm{D}}=3.9 \mathrm{~Hz}, 1 \mathrm{H}, \mathrm{H}^{\mathrm{D}_{\text {eq }}}\right), 3.78-3.65\left(\mathrm{~m}, 2 \mathrm{H}, \mathrm{H}^{\mathrm{B}}\right.$, $\left.\mathrm{H}^{\mathrm{B}}, \mathrm{H}^{\mathrm{C}}\right), 3.51-3.44\left(\mathrm{~m}, 2 \mathrm{H}, \mathrm{H} 5^{\mathrm{A}}, \mathrm{H} 5^{\mathrm{C}}\right), 3.33\left(\mathrm{dd}, J_{5 \mathrm{Dax}, 5 \mathrm{Deq}}=12.4 \mathrm{~Hz}\right.$, $\left.J_{5 \mathrm{Dax}, 4 \mathrm{D}}=6.3 \mathrm{~Hz}, 1 \mathrm{H}, \mathrm{H}^{\mathrm{D}} \mathrm{ax}_{\mathrm{ax}}\right), 3.28\left(\mathrm{dd}, J_{5 \mathrm{Bax}, 5 \mathrm{Beq}}=11.7 \mathrm{~Hz}, J_{5 \mathrm{Bax}, 4 \mathrm{~B}}=7.9\right.$ $\mathrm{Hz}, 1 \mathrm{H}, \mathrm{H}^{\mathrm{B}} \mathrm{ax}$ ), 3.01 (dd, $J_{5 \mathrm{Cax}, 5 \mathrm{Ceq}}=12.2 \mathrm{~Hz}, J_{5 \mathrm{Cax}, 4 \mathrm{C}}=9.1 \mathrm{~Hz}, 1 \mathrm{H}$, $\left.\mathrm{H}^{\mathrm{C}} \mathrm{ax}\right), 2.61-2.46(\mathrm{~m}, 2 \mathrm{H}), 2.44-2.30(\mathrm{~m}, 2 \mathrm{H}), 2.06(\mathrm{~s}, 3 \mathrm{H}) .{ }^{13} \mathrm{C}$ NMR $\left(101 \mathrm{MHz}, \mathrm{CDCl}_{3}\right): \delta=205.8,171.2,165.6,165.5(\times 2), 165.4,165.3$, 
$165.3,165.1,165.0,133.5,133.5,133.4,133.4,133.3,133.1,132.9$, $132.6,130.1,130.0,130.0,129.9,129.9,129.9,129.8,129.8,129.7$, $129.6,129.5,129.5,129.4,129.3,129.1,129.1,129.0,128.6,128.5$, 128.5, 128.5, 128.4, 128.1, $100.8\left(\mathrm{C}^{\mathrm{B}}\right), 100.6\left(\mathrm{C} 1^{\mathrm{C}}\right), 99.5\left(\mathrm{C} 1^{\mathrm{D}}\right), 86.7$ $\left(\mathrm{C} 1^{\mathrm{A}}\right), 75.4\left(\mathrm{C} 4^{\mathrm{A}}\right), 75.3,75.1\left(\mathrm{C} 4^{\mathrm{B}}, \mathrm{C}^{\mathrm{C}}\right), 73.0\left(\mathrm{C}^{\mathrm{A}}\right), 72.5\left(\mathrm{C} 3^{\mathrm{C}}\right), 71.9$ $\left(\mathrm{C} 3^{\mathrm{B}}\right), 71.4,71.3\left(\mathrm{C} 2^{\mathrm{B}}, \mathrm{C} 2^{\mathrm{C}}\right), 70.5\left(\mathrm{C} 2^{\mathrm{A}}\right), 70.1\left(\mathrm{C} 2^{\mathrm{D}}\right), 69.6\left(\mathrm{C} 3^{\mathrm{D}}\right), 68.6$ $\left(C 4^{\mathrm{D}}\right), 65.7\left(\mathrm{C}^{\mathrm{A}}\right), 62.4,62.3\left(\mathrm{C5}^{\mathrm{B}}, \mathrm{C}^{\mathrm{C}}\right), 60.9\left(\mathrm{C} 5^{\mathrm{D}}\right), 37.8,29.8,27.9$. HRMS: calcd. for $\mathrm{C}_{87} \mathrm{H}_{76} \mathrm{O}_{26} \mathrm{SNa}[\mathrm{M}+\mathrm{Na}]^{+}$1591.4237; found 1591.4254.

Benzyl 2,3,4-tri-O-benzoyl- $\beta$-D-xylopyranosyl-(1 $\rightarrow 4)-3-O-$-benzoyl-2O-levulinoyl- $\beta$-D-xylopyranosyl-(1 $\rightarrow 4)-2,3-d i-O$-benzoyl- $\beta$-Dxylopyranosyl-( $1 \rightarrow 4)$-2,3-di-O-benzoyl- $\beta$-D-xylopyranoside-( $\rightarrow 4$ )2,3-di-O-benzoyl- $\beta$-D-xylopyranoside (14): General procedure $A$ Crushed molecular sieves $(0.754 \mathrm{~g})$. Donor $13(0.400 \mathrm{~g}, 0.26 \mathrm{mmol})$. AgOTf $(0.1317 \mathrm{~g}, 0.51 \mathrm{mmol})$. $p$-Nitrobenzenesulfenyl chloride $(0.048 \mathrm{~g}$ $0.26 \mathrm{mmol})$. Acceptor $9(0.103 \mathrm{~g}, 0.23 \mathrm{mmol})$. Reaction time $90 \mathrm{~min} . \mathrm{Et}_{3} \mathrm{~N}$ $(0.11 \mathrm{~mL}, 0.77 \mathrm{mmol})$. Eluent for flash column chromatography hexane/toluene/EtOAc 4:3:2. The product was obtained as a white crystalline solid $(0.364 \mathrm{~g}, 83 \%)$. $R_{\mathrm{f}}=0.33$ (hexane/toluene/EtOAc 3:3:2). $[\alpha]_{D}^{25}=-43.0\left(\right.$ c $\left.0.10, \mathrm{CHCl}_{3}\right) .{ }^{1} \mathrm{H}$ NMR $\left(400 \mathrm{MHz}, \mathrm{CDCl}_{3}\right): \delta=7.98-7.85$ $(\mathrm{m}, 20 \mathrm{H}), 7.57-7.49(\mathrm{~m}, 6 \mathrm{H}), 7.45-7.16(\mathrm{~m}, 29 \mathrm{H}), 5.57(\mathrm{t}, J=6.7 \mathrm{~Hz}, 1 \mathrm{H}$ $\left.\mathrm{H}^{\mathrm{E}}\right), 5.55-5.51\left(\mathrm{~m}, 1 \mathrm{H}, \mathrm{H} 3^{\mathrm{A}}\right), 5.49\left(\mathrm{t}, J=8.0 \mathrm{~Hz}, 1 \mathrm{H}, \mathrm{H} 3^{\mathrm{B}}\right), 5.40$ (t, $J=$ $\left.8.0 \mathrm{~Hz}, 1 \mathrm{H}, \mathrm{H}^{\mathrm{C}}\right), 5.31-5.27\left(\mathrm{~m}, 2 \mathrm{H}, \mathrm{H}^{\mathrm{A}}, \mathrm{H}^{\mathrm{D}}\right), 5.15(\mathrm{dd}, J=8.4,6.6 \mathrm{~Hz}$, $1 \mathrm{H}, \mathrm{H} 2^{\mathrm{B}}$ ), $5.12\left(\mathrm{dd}, J=6.9,5.1 \mathrm{~Hz}, 1 \mathrm{H}, \mathrm{H}^{\mathrm{E}}\right), 5.08-5.01\left(\mathrm{~m}, 2 \mathrm{H}, \mathrm{H}^{\mathrm{C}}\right.$, $\mathrm{H} 4 \mathrm{E}), 4.84-4.80\left(\mathrm{~m}, 1 \mathrm{H}, \mathrm{H} 2^{\mathrm{D}}\right), 4.80(\mathrm{~d}, J=12.5 \mathrm{~Hz}, 1 \mathrm{H}, \mathrm{Bn}), 4.70(\mathrm{~d}, J=$ $\left.6.3 \mathrm{~Hz}, 1 \mathrm{H}, \mathrm{H} 1^{\mathrm{B}}\right), 4.66\left(\mathrm{~d}, J=4.9 \mathrm{~Hz}, 1 \mathrm{H}, \mathrm{H} 1^{\mathrm{E}}\right), 4.64(\mathrm{~d}, J=6.6 \mathrm{~Hz}, 1 \mathrm{H}$, $\mathrm{H}^{\mathrm{A}}{ }^{\mathrm{A}}, 4.55(\mathrm{~d}, J=12.4 \mathrm{~Hz}, 1 \mathrm{H}, \mathrm{Bn}), 4.54\left(\mathrm{~d}, J=6.0 \mathrm{~Hz}, 1 \mathrm{H}, \mathrm{H} 1^{\mathrm{C}}\right) 4.33(\mathrm{~d}$, $\left.J=6.7 \mathrm{~Hz}, 1 \mathrm{H}, \mathrm{H}^{\mathrm{D}}\right), 3.99-3.94\left(\mathrm{~m}, 3 \mathrm{H}, \mathrm{H} 4^{\mathrm{A}}, \mathrm{H} 5^{\mathrm{A}}, \mathrm{H} 5^{\mathrm{E}}\right), 3.80-3.73(\mathrm{~m}$, $2 \mathrm{H}, \mathrm{H}^{\mathrm{B}}, \mathrm{H} 4^{\mathrm{D}}$ ), 3.69 (td, $J=8.0,7.5,4.4 \mathrm{~Hz}, 1 \mathrm{H}, \mathrm{H}^{\mathrm{C}}$ ), 3.60 (dd, $J=12.1$, $\left.4.8 \mathrm{~Hz}, 1 \mathrm{H}, \mathrm{H} 5^{\mathrm{C}}\right), 3.48-3.43\left(\mathrm{~m}, 2 \mathrm{H}, \mathrm{H} 5^{\mathrm{B}}, \mathrm{H} 5^{\mathrm{D}}\right), 3.40-3.31\left(\mathrm{~m}, 2 \mathrm{H}, \mathrm{H} 5^{\mathrm{A}}\right.$, $\mathrm{H} 5^{ } \mathrm{E}$ ), $3.20\left(\mathrm{dd}, J=12.2,8.4 \mathrm{~Hz}, 1 \mathrm{H}, \mathrm{H}^{\mathrm{C}} \mathrm{C}\right.$ ), 3.09 (dd, $J=12.2,8.6 \mathrm{~Hz}, 1 \mathrm{H}$ $\left.\mathrm{H} 5^{\prime} \mathrm{B}\right), 3.00$ (dd, $\left.J=12.2,9.0 \mathrm{~Hz}, 1 \mathrm{H}, \mathrm{H} 5^{\prime} \mathrm{D}\right), 2.53(\mathrm{q}, J=6.7 \mathrm{~Hz}, 2 \mathrm{H}$ ), 2.38-2.33 (m, 2H), $2.05(\mathrm{~s}, 3 \mathrm{H}) .{ }^{13} \mathrm{C}$ NMR $\left(101 \mathrm{MHz}, \mathrm{CDCl}_{3}\right): \delta=205.7$, $171.2,165.6,165.5,165.4,165.4,165.4,165.3(\times 2), 165.1,165.0,165.0$, $136.9,133.5,133.5,133.4,133.4,133.3,133.2,133.1,133.1,130.0$, $130.0,130.0,129.9,129.8,129.8,129.7,129.7,129.7,129.6,129.6$, $129.5,129.4,129.4,129.3,129.1,129.0,128.6,128.6,128.5,128.5$, $128.5,128.4,128.4,128.4,128.3,127.9,127.9,101.1\left(\mathrm{C} 1^{\mathrm{B}}\right), 100.6$, 100.5 (C1 $\left.{ }^{\mathrm{C}}, \mathrm{C} 1^{\mathrm{D}}\right), 99.5,99.4$ (C1A, C1E), $76.1\left(\mathrm{C} 4^{\mathrm{A}}\right), 75.3,75.2,75.0$ (C4 $\left.\mathrm{C} 4^{\mathrm{C}}, \mathrm{C} 4^{\mathrm{D}}\right), 72.5\left(\mathrm{C} 3^{\mathrm{D}}\right), 72.2,72.1,72.0\left(\mathrm{C}^{\mathrm{A}}, \mathrm{C}^{\mathrm{B}}, \mathrm{C} 3^{\mathrm{E}}\right), 71.5,71.4\left(\mathrm{C}^{\mathrm{B}}\right.$, $\left.\mathrm{C} 2^{\mathrm{D}}\right), 71.2\left(\mathrm{C}^{\mathrm{C}}\right), 71.1\left(\mathrm{C} 2^{\mathrm{A}}\right), 70.4(\mathrm{Bn}), 70.1\left(\mathrm{C} 2^{\mathrm{E}}\right), 69.6\left(\mathrm{C} 3^{\mathrm{E}}\right), 68.6$ $\left(\mathrm{C} 4^{\mathrm{E}}\right), 62.7\left(\mathrm{C} 5^{\mathrm{A}}\right), 62.4,62.3(\times 2)\left(\mathrm{C}^{\mathrm{B}}, \mathrm{C} 5^{\mathrm{C}}, \mathrm{C} 5^{\mathrm{D}}\right), 60.9\left(\mathrm{C} 5^{\mathrm{E}}\right), 37.8,29.7$, 27.9. HRMS: calcd. for $\mathrm{C}_{107} \mathrm{H}_{94} \mathrm{O}_{33} \mathrm{Na}\left[\mathrm{M}+\mathrm{Na}^{+}\right.$1930.5603; found 1930.5619 .

Benzyl 2,3,4-tri-O-benzoyl- $\beta$-D-xylopyranosyl-(1 $\rightarrow 4)$-3-O-benzoyl- $\beta$-Dxylopyranosyl-(1 $\rightarrow 4)$-2,3-di-O-benzoyl- $\beta$-D-xylopyranosyl-( $1 \rightarrow 4)-2,3$ di-O-benzoyl- $\beta$-D-xylopyranoside-( $1 \rightarrow 4)-2,3-d i-O$-benzoyl- $\beta$-Dxylopyranoside (15): Pentasaccharide $14(1.740 \mathrm{~g}, 0.912 \mathrm{mmol})$ was dissolved in pyridine/AcOH 2:1 $(1.80 \mathrm{~mL})$. A mixture of a $50 \%$ solution of hydrazine hydrate $(88 \mu \mathrm{L}, 1.82 \mathrm{mmol})$ dissolved in pyridine $(\mathrm{C}=20 \mathrm{M})$ was added at $0{ }^{\circ} \mathrm{C}$. The reaction was left to stir at r.t. overnight, at which point TLC showed consumption of the starting material and formation of the product. The reaction was stopped by addition of acetone $(34.0 \mathrm{~mL}$, $456 \mathrm{mmol}$ ) and was left to stir at r.t. for $1 \mathrm{~h}$. EtOAc was added, and the mixture washed with $1 \mathrm{M} \mathrm{HCl}$ and brine, filtered, and conc. in vacuo. The residue was purified by flash column chromatography (hexane/toluene/EtOAc 3:3:2) affording the product as a white powder $(1.610 \mathrm{~g}, 97 \%) . R_{\mathrm{f}}=0.34$ (hexane/toluene/EtOAc 3:3:2). $[\alpha]_{\mathrm{D}}^{25}=-38.3(c 1$, $\left.\mathrm{CHCl}_{3}\right) .{ }^{1} \mathrm{H}$ NMR $\left(400 \mathrm{MHz}, \mathrm{CDCl}_{3}\right): \delta=8.02-7.84(\mathrm{~m}, 2 \mathrm{H}), 7.59-7.30$ $(\mathrm{m}, 30 \mathrm{H}), 7.22-7.16(\mathrm{~m}, 5 \mathrm{H}), 5.64\left(\mathrm{t}, J=6.7 \mathrm{~Hz}, 1 \mathrm{H}, \mathrm{H}^{\mathrm{E}}\right), 5.52(\mathrm{t}, J=8.1$ $\left.\mathrm{Hz}, 1 \mathrm{H}, \mathrm{H}^{\mathrm{A}}\right), 5.49\left(\mathrm{t}, J=8.1 \mathrm{~Hz}, 1 \mathrm{H}, \mathrm{H}^{\mathrm{B}}\right), 5.40\left(\mathrm{t}, J=7.9 \mathrm{~Hz}, 1 \mathrm{H}, \mathrm{H} 3^{\mathrm{C}}\right)$, $5.29\left(\mathrm{dd}, J=8.5,6.7 \mathrm{~Hz}, 1 \mathrm{H}, \mathrm{H}^{\mathrm{A}}\right), 5.21\left(\mathrm{t}, J=7.4 \mathrm{~Hz}, 1 \mathrm{H}, \mathrm{H} 3^{\mathrm{D}}\right.$ ), $5.18-$ $5.09\left(\mathrm{~m}, 3 \mathrm{H}, \mathrm{H}^{\mathrm{B}}, \mathrm{H} 2^{\mathrm{E}}, \mathrm{H} 4^{\mathrm{E}}\right), 5.06\left(\mathrm{dd}, J=8.1,6.1 \mathrm{~Hz}, 1 \mathrm{H}, \mathrm{H}^{\mathrm{C}}\right), 4.80(\mathrm{~d}$, $J=12.3 \mathrm{~Hz}, 1 \mathrm{H}, \mathrm{Bn}), 4.72(\mathrm{~d}, J=4.9 \mathrm{~Hz}, 1 \mathrm{H}, \mathrm{H} 1 \mathrm{E}), 4.70(\mathrm{~d}, J=6.4 \mathrm{~Hz}$, $\left.1 \mathrm{H}, \mathrm{H} 1^{\mathrm{B}}\right), 4.63\left(\mathrm{~d}, J=6.6 \mathrm{~Hz}, 1 \mathrm{H}, \mathrm{H} 1^{\mathrm{A}}\right), 4.54\left(\mathrm{~d}, J=5.3 \mathrm{~Hz}, 1 \mathrm{H}, \mathrm{H} 1^{\mathrm{C}}\right)$, 4.55 (d, $J=12.5 \mathrm{~Hz}, 1 \mathrm{H}, \mathrm{Bn}), 4.27$ (d, $J=5.6 \mathrm{~Hz}, 1 \mathrm{H}, \mathrm{H}^{\mathrm{D}}$ ), 4.15 (dd, $J=$ 12.4, 3.9 Hz, $\left.1 \mathrm{H}, \mathrm{H} 5^{\mathrm{E}}\right), 4.00-3.94\left(\mathrm{~m}, 2 \mathrm{H}, \mathrm{H} 4^{\mathrm{A}}, \mathrm{H} 5^{\mathrm{A}}\right), 3.79-3.70(\mathrm{~m}, 3 \mathrm{H}$, $\left.\mathrm{H} 4^{\mathrm{B}}, \mathrm{H}^{\mathrm{C}}, \mathrm{H} 4^{\mathrm{D}}\right), 3.63-3.57\left(\mathrm{~m}, 2 \mathrm{H}, \mathrm{H}^{\mathrm{C}}, \mathrm{H} 5^{\mathrm{D}}\right), 3.47-3.43\left(\mathrm{~m}, 3 \mathrm{H}, \mathrm{H} 5^{\mathrm{B}}\right.$,
$\left.\mathrm{H} 2^{\mathrm{D}}, \mathrm{H} 5^{\prime} \mathrm{E}\right), 3.37$ (td, $\left.J=10.1,3.5 \mathrm{~Hz}, 1 \mathrm{H}, \mathrm{H} 5^{\prime A}\right), 3.14(\mathrm{dd}, J=12.0,7.7$ $\left.\mathrm{Hz}, 1 \mathrm{H}, \mathrm{H} 5^{\prime} \mathrm{C}\right), 3.12-3.03\left(\mathrm{~m}, 2 \mathrm{H}, \mathrm{H} 5^{\prime}{ }^{\mathrm{B}}, \mathrm{H} 5^{\prime} \mathrm{D}\right) .{ }^{13} \mathrm{C}$ NMR $(101 \mathrm{MHz}$ $\left.\mathrm{CDCl}_{3}\right): \delta=166.1,165.6,165.5(\times 2), 165.5,165.4,165.3,165.3,165.1$ $165.0,136.9,133.6,133.6,133.5,133.4,133.4,133.3,133.3,133.2$ $133.1,130.1,130.0,130.0,129.9,129.9,129.8,129.8,129.8,129.7$ $129.6,129.6,129.6,129.5,129.4,129.3,129.2,129.0,128.6,128.6$ $128.5,128.4,128.4,128.3,127.9,127.9,101.7\left(\mathrm{C} 1^{\mathrm{D}}, \mathrm{J}_{\mathrm{C}-\mathrm{H}}=164 \mathrm{~Hz}\right)$, $101.2\left(\mathrm{C} 1^{\mathrm{B}}, \mathrm{JC}_{\mathrm{C}-\mathrm{H}}=162 \mathrm{~Hz}\right), 100.6\left(\mathrm{C} 1^{\mathrm{C}}, \mathrm{JC}_{\mathrm{H}} \mathrm{H}=162 \mathrm{~Hz}\right), 99.4\left(\mathrm{C} 1^{\mathrm{A}}, \mathrm{JC}_{\mathrm{C}-\mathrm{H}}=\right.$ $163 \mathrm{~Hz}), 99.0\left(\mathrm{C} 1^{\mathrm{E}}, \mathrm{J}_{\mathrm{C}-\mathrm{H}}=165 \mathrm{~Hz}\right), 76.2\left(\mathrm{C} 4^{\mathrm{A}}\right), 75.4\left(\mathrm{C} 4^{\mathrm{B}}\right), 74.0\left(\mathrm{C}^{\mathrm{C}}\right.$, $\left.\mathrm{C} 4^{\mathrm{D}}\right), 73.2\left(\mathrm{C} 3^{\mathrm{D}}\right), 72.3,72.2\left(\mathrm{C}^{\mathrm{A}}, \mathrm{C}^{\mathrm{B}}\right), 71.8\left(\mathrm{C}^{\mathrm{C}}\right), 71.6\left(\mathrm{C}^{\mathrm{B}}\right), 71.2$ $71.1(2 \mathrm{C})\left(\mathrm{C}^{\mathrm{A}}, \mathrm{C} 2^{\mathrm{C}}, \mathrm{C} 2^{\mathrm{D}}\right), 70.4\left(\mathrm{OCH}_{2} \mathrm{Ph}\right), 70.2\left(\mathrm{C}^{\mathrm{E}}\right), 69.5\left(\mathrm{C} 3^{\mathrm{E}}\right), 68.6$ $\left(\mathrm{C} 4^{\mathrm{E}}\right), 62.7\left(\mathrm{C}^{\mathrm{A}}\right), 62.4\left(\mathrm{C} 5^{\mathrm{B}}\right), 62.0\left(\mathrm{C}^{\mathrm{C}}\right), 61.3\left(\mathrm{C} 5^{\mathrm{D}}\right), 61.0\left(\mathrm{C} 5^{\mathrm{E}}\right)$. HRMS: calcd. for $\mathrm{C}_{102} \mathrm{H}_{88} \mathrm{O}_{31} \mathrm{Na}[\mathrm{M}+\mathrm{Na}]^{+} 1831.5202$; found 1831.5112 .

Benzyl 2,3,4-tri-O-benzoyl- $\beta$-D-xylopyranosyl-(1 $\rightarrow 4)-3-O$-benzoyl-2$O$-[methyl 2,3,4-tri-O-benzyl-D-glucopyranosyluronate]- $\beta$-Dxylopyranosyl-( $1 \rightarrow 4)-2,3$-di-O-benzoyl- $\beta$-D-xylopyranosyl-( $1 \rightarrow 4)-2,3-$ di-O-benzoyl- $\beta$-D-xylopyranosyl-( $1 \rightarrow 4)-2,3-d i-O$-benzoyl- $\beta-D-$

xylopyranoside (18): General procedure B: Crushed molecular sieves $(0.395 \mathrm{~g})$. Donor $16(0.281 \mathrm{~g}, 0.54 \mathrm{mmol})$. Acceptor 15 (0.243 g, 0.13 mmol). $\mathrm{AgClO}_{4}(0.133 \mathrm{~g}, 0.64 \mathrm{mmol})$. Et ${ }_{3} \mathrm{~N}(0.09 \mathrm{~mL}, 0.67 \mathrm{mmol})$. Eluent for flash column chromatography heptane/toluene/acetone 4:1:1 (elution of product) and heptane/toluene/acetone 2:1:1 (elution of acceptor). The product was obtained as a white crystalline anomeric mixture $(\alpha / \beta 4: 1)$ $(0.138 \mathrm{~g}, 45 \%)$, and acceptor 15 was furthermore reisolated $(0.057 \mathrm{~g}$, $23 \%$ ). $R_{f}=0.50$ (heptane/toluene/acetone 2:1:2). For the $\alpha$-glucuronide (including partial NMR data for the $\beta$-isomer): ${ }^{1} \mathrm{H} \mathrm{NMR}\left(400 \mathrm{MHz}, \mathrm{CDCl}_{3}\right)$ : $\delta=8.03-7.82(\mathrm{~m}, 28 \mathrm{H}), 7.59-7.15(\mathrm{~m}, 75 \mathrm{H}), 7.01-6.98(\mathrm{~m}, 2 \mathrm{H}), 5.57-$ $5.24\left(\mathrm{~m}, 9 \mathrm{H}, \mathrm{H}^{\mathrm{A}}, \mathrm{H} 3^{\mathrm{A}}, \mathrm{H} 2^{\mathrm{B}}, \mathrm{H} 3^{\mathrm{C}}, \mathrm{H} 3^{\mathrm{D}}, \mathrm{H} 3^{\mathrm{E}}, \mathrm{H} 1^{\mathrm{F}}\right), 5.12(\mathrm{dd}, J=8.0,6.4$ $\mathrm{Hz}, 1 \mathrm{H}, \mathrm{H}^{\mathrm{B}}$ ), 5.08 (dd, $J=6.8,5.0 \mathrm{~Hz}, 1 \mathrm{H}, \mathrm{H}^{\mathrm{E}}$ ), 4.97 (td, $J=6.4,4.2 \mathrm{~Hz}$, $1 \mathrm{H}, \mathrm{H}^{\mathrm{E}}$ ), $4.92\left(\mathrm{dd}, J=7.3,5.5 \mathrm{~Hz}, 1 \mathrm{H}, \mathrm{H} 2^{\mathrm{C}}\right.$ ), $4.85-4.52\left(\mathrm{~m}, 14 \mathrm{H}, \mathrm{H} 1^{\mathrm{A}}\right.$, $\left.\mathrm{H} 1^{\mathrm{B}}, \mathrm{H} 1^{\mathrm{E}}, \mathrm{Bn}\right), 4.44(\mathrm{~d}, J=3.4 \mathrm{~Hz}, 0.25 \mathrm{H}), 4.39(\mathrm{~d}, J=5.4 \mathrm{~Hz}, 0.25 \mathrm{H})$, $4.34(\mathrm{~d}, J=11.2 \mathrm{~Hz}, 1 \mathrm{H}), 4.22\left(\mathrm{~d}, J=7.2 \mathrm{~Hz}, 1 \mathrm{H}, \mathrm{H} 1^{\mathrm{D}}\right), 4.17(\mathrm{~d}, J=5.4$ $\left.\mathrm{Hz}, 1 \mathrm{H}, \mathrm{H} 1^{\mathrm{C}}\right), 4.08(\mathrm{~d}, J=10.0 \mathrm{~Hz}, 1 \mathrm{H}), 4.01-3.93\left(\mathrm{~m}, 2.5 \mathrm{H}, \mathrm{H} 4^{\mathrm{A}}, \mathrm{H} 5^{\mathrm{A}}\right.$, $\mathrm{Bn}), 3.89-3.79\left(\mathrm{~m}, 3 \mathrm{H}, \mathrm{H} 5^{\mathrm{E}}\right), 3.72-3.58\left(\mathrm{~m}, 5.5 \mathrm{H}, \mathrm{H} 4^{\mathrm{B}}, \mathrm{H} 2^{\mathrm{D}}, \mathrm{H} 4^{\mathrm{D}}\right), 3.56-$ $3.44\left(\mathrm{~m}, 7 \mathrm{H}, \mathrm{H} 5^{\mathrm{B}}, \mathrm{H}^{\mathrm{C}}, \mathrm{H} 5^{\mathrm{C}}, \mathrm{H} 5^{\mathrm{D}}\right), 3.40(\mathrm{~s}, 3 \mathrm{H}, \mathrm{COOMe}), 3.37-3.33(\mathrm{~m}$ $\left.1 \mathrm{H}, \mathrm{H} 5^{\mathrm{A}} \mathrm{A}\right), 3.26-3.20\left(\mathrm{~m}, 2 \mathrm{H}, \mathrm{H} 5^{ } \mathrm{E}\right), 3.11-2.97\left(\mathrm{~m}, 2 \mathrm{H}, \mathrm{H} 5^{\circ}, \mathrm{H} 5^{\circ} \mathrm{C}\right), 2.96-$ $2.91\left(\mathrm{~m}, 1 \mathrm{H}, \mathrm{H} 5{ }^{\circ}\right) \cdot{ }^{13} \mathrm{C}$ NMR $\left(101 \mathrm{MHz}, \mathrm{CDCl}_{3}\right): \delta=170.2,169.0\left(\mathrm{C}_{\beta}\right)$ $165.7,165.5,165.4,165.4,165.4,165.3,165.1,165.0,165.0,138.6$ $138.4,138.3,136.9,133.5,133.5,133.4,133.3,133.2,133.2,133.1$ $133.1,130.2,130.1,130.1,130.0,129.9,129.9,129.8,129.8,129.6$, $129.4,129.3,129.2,129.0,128.6,128.6,128.5,128.4,128.4,128.4$ $128.3,128.2,128.1,128.1,128.0,127.9,127.9,127.8,127.5,127.4$ 102.2 $\left(\mathrm{C} 1^{\mathrm{D}}\right), 101.0\left(\mathrm{C} 1^{\mathrm{B}}\right), 99.8,99.5,99.3\left(\mathrm{C} 1^{\mathrm{A}}, \mathrm{C} 1^{\mathrm{C}}, \mathrm{C} 1^{\mathrm{E}}\right), 97.3\left(\mathrm{C} 1^{\mathrm{F}}\right.$ $\left.J_{C}-\mathrm{H}=173 \mathrm{~Hz}\right), 80.7\left(\mathrm{C}^{\mathrm{F}}\right), 80.0\left(\mathrm{C} 4^{\mathrm{F}}\right), 79.3\left(\mathrm{C} 2^{\mathrm{F}}\right), 76.6\left(\mathrm{C}^{\mathrm{D}}\right), 76.2,76.1$ $\left(\mathrm{C}^{\mathrm{A}}, \mathrm{C}^{\mathrm{D}}\right), 75.8(\mathrm{Bn}), 74.5(\mathrm{Bn}), 74.1\left(\mathrm{C}^{\mathrm{B}}\right), 73.7\left(\mathrm{C}^{\mathrm{D}}\right), 73.5(\mathrm{Bn}), 73.4$ $\left(\mathrm{C} 4^{\mathrm{C}}\right), 72.4\left(\mathrm{C}^{\mathrm{A}}\right), 71.8\left(\mathrm{C}^{\mathrm{B}}\right), 71.4\left(\mathrm{C}^{\mathrm{B}}\right), 71.2,71.1,70.8\left(\mathrm{C2}^{\mathrm{A}}, \mathrm{C}^{\mathrm{C}}\right.$, $\left.\mathrm{C}^{\mathrm{C}}\right), 70.5\left(\mathrm{C} 5^{\mathrm{F}}\right), 70.4(\mathrm{Bn}), 70.3\left(\mathrm{C}^{\mathrm{E}}\right), 69.7\left(\mathrm{C} 3^{\mathrm{E}}\right), 68.7\left(\mathrm{C} 4^{\mathrm{E}}\right), 63.1,62.8$ $\left(\mathrm{C} 5^{\mathrm{A}}, \mathrm{C} 5^{\mathrm{D}}\right), 61.9\left(\mathrm{C}^{\mathrm{B}}\right), 61.4\left(\mathrm{C}^{\mathrm{C}}\right), 60.9\left(\mathrm{C} 5^{\mathrm{E}}\right), 52.6\left(\mathrm{C}_{\beta}\right), 52.1(\mathrm{COOMe})$ HRMS: calcd. for $\mathrm{C}_{130} \mathrm{H}_{116} \mathrm{O}_{37} \mathrm{Na}[\mathrm{M}+\mathrm{Na}]^{+} 2291.7088$; found 2291.7098 .

Benzyl 2,3,4-tri-O-benzoyl- $\beta$-D-xylopyranosyl-(1 $\rightarrow 4)-3-O-$-benzoyl-2$O$-[methyl 2,3-di-O-benzyl-4-O-methyl-D-glucopyranosyluronate]- $\beta$-Dxylopyranosyl-( $1 \rightarrow 4)$-2,3-di-O-benzoyl- $\beta$-D-xylopyranosyl-( $1 \rightarrow 4)-2,3-$ di-O-benzoyl- $\beta$-D-xylopyranosyl-( $1 \rightarrow 4)-2,3-d i-O$-benzoyl- $\beta$-D-

xylopyranoside (19): General procedure B: Crushed molecular sieves (0.372 g). Donor 17 (0.197 g, $0.44 \mathrm{mmol})$. Acceptor 15 (0.200 g, 0.11 mmol). $\mathrm{AgClO}_{4}(0.111 \mathrm{~g}, 0.53 \mathrm{mmol})$. Et $3 \mathrm{~N}(0.08 \mathrm{~mL}, 0.55 \mathrm{mmol})$. Eluent for flash column chromatography heptane/toluene/acetone 6:3:2. The product was obtained as a white crystalline anomeric mixture ( $\alpha / \beta 5: 2)$ $(0.106 \mathrm{~g}, 44 \%)$, and acceptor 15 was furthermore reisolated $(0.034 \mathrm{~g}$, $17 \%) . R_{f}=0.45$ (heptane/toluene/acetone 2:1:2). For the $\alpha$-glucuronide (including partial NMR data for the $\beta$-isomer): ${ }^{1} \mathrm{H} \mathrm{NMR}\left(400 \mathrm{MHz}, \mathrm{CDCl}_{3}\right)$ : $\delta=8.04-7.83(\mathrm{~m}, 33 \mathrm{H}), 7.59-7.11(\mathrm{~m}, 79 \mathrm{H}), 5.58-5.24\left(\mathrm{~m}, 10.7 \mathrm{H}, \mathrm{H} 2^{\mathrm{A}}\right.$, $\mathrm{H}^{\mathrm{A}}, \mathrm{H}^{\mathrm{B}}, \mathrm{H}^{\mathrm{C}}, \mathrm{H} 3^{\mathrm{D}}, \mathrm{H} 3^{\mathrm{E}}, \mathrm{H} 1^{\mathrm{F}}$ ), 5.17-5.06 (m, 3H, H2 $2^{\mathrm{B}}, \mathrm{H}^{\mathrm{E}}$ ), 5.04 (dd, $J$ $=7.0,5.1 \mathrm{~Hz}, 0.4 \mathrm{H}), 5.00-4.93(\mathrm{~m}, 1.6 \mathrm{H}, \mathrm{H} 4 \mathrm{E}), 4.90(\mathrm{dd}, J=7.5,5.6 \mathrm{~Hz}$, $\left.1 \mathrm{H}, \mathrm{H}^{\mathrm{C}}\right), 4.83-4.82(\mathrm{~m}, 2.8 \mathrm{H}, \mathrm{Bn}), 4.79-4.73(\mathrm{~m}, 2 \mathrm{H}), 4.71-4.68(\mathrm{~m}$, 2.4H, $\left.\mathrm{H}^{\mathrm{B}}, \mathrm{Bn}\right), 4.66-4.60\left(\mathrm{~m}, 3.7 \mathrm{H}, \mathrm{H} 1 \mathrm{~A}, \mathrm{H}^{\mathrm{E}}, \mathrm{Bn}\right), 4.57-4.52(\mathrm{~m}, 3.3 \mathrm{H}$, $\mathrm{Bn}), 4.50(\mathrm{~d}, J=5.1 \mathrm{~Hz}, 0.4 \mathrm{H}), 4.45(\mathrm{~d}, J=11.5 \mathrm{~Hz}, 0.4 \mathrm{H}), 4.39(\mathrm{~d}, J=$ 
$5.4 \mathrm{~Hz}, 0.4 \mathrm{H}), 4.21\left(\mathrm{~d}, J=7.1 \mathrm{~Hz}, 1 \mathrm{H}, \mathrm{H}^{\mathrm{D}}\right), 4.13\left(\mathrm{~d}, J=5.6 \mathrm{~Hz}, 1 \mathrm{H}, \mathrm{H} 1^{\mathrm{C}}\right)$, 4.02-3.95 (m, 4H, H4 $\left.4^{\mathrm{A}}, \mathrm{H} 5^{\mathrm{A}}, \mathrm{H} 5^{\mathrm{F}}\right), 3.89-3.56\left(\mathrm{~m}, 11.3 \mathrm{H}, \mathrm{H} 4^{\mathrm{B}}, \mathrm{H} 2^{\mathrm{D}}, \mathrm{H} 4^{\mathrm{D}}\right.$, $\left.\mathrm{H}^{\mathrm{E}}, \mathrm{H} 3^{\mathrm{F}}\right), 3.53-3.34$ (m, 14H, H5'A $\left.\mathrm{H}^{\mathrm{B}}, \mathrm{H} 4^{\mathrm{C}}, \mathrm{H} 5^{\mathrm{C}}, \mathrm{H}^{\mathrm{D}}, \mathrm{H} 2^{\mathrm{F}}, \mathrm{COOMe}\right)$, 3.29-3.18 (m, 7.4H, H5 $\left.5^{\mathrm{E}}, \mathrm{H}^{\mathrm{F}}, \mathrm{OMe}\right), 3.11-3.02\left(\mathrm{~m}, 2 \mathrm{H}, \mathrm{H} 5^{\mathrm{B}}\right), 2.99(\mathrm{dd}$ $\left.J=11.4,6.8 \mathrm{~Hz}, 1 \mathrm{H}, \mathrm{H} 5^{\prime} \mathrm{C}\right), 2.95-2.89\left(\mathrm{~m}, 1 \mathrm{H}, \mathrm{H} 5^{\prime} \mathrm{D}\right) .{ }^{13} \mathrm{C} \mathrm{NMR}(101 \mathrm{MHz}$, $\left.\mathrm{CDCl}_{3}\right): \delta=170.3,169.1,165.7,165.5,165.4,165.4,165.4,165.3,165.3$ $165.3\left(\mathrm{C}_{\beta}\right), 165.2\left(\mathrm{C}_{\beta}\right), 165.1,165.0\left(\mathrm{C}_{\beta}\right), 164.9,164.9,138.7,138.6\left(\mathrm{C}_{\beta}\right)$, $138.5,136.9,133.5,133.5,133.4,133.3,133.2,133.2,133.1,133.0$, 130.2, 130.1, 130.1, 130.1, 123.0, 129.9, 129.9, 129.8, 129.8, $129.7\left(\mathrm{C}_{\beta}\right)$, $129.6\left(C_{\beta}\right), 129.6,129.6,129.5\left(C_{\beta}\right), 129.4\left(C_{\beta}\right), 129.4,129.3,129.3\left(C_{\beta}\right)$, $129.2,129.0,128.6,128.5,128.4,128.4,128.4,128.3,128.2,128.2$, $128.1,128.0,127.9,127.9,127.8,127.7\left(C_{\beta}\right), 127.6\left(C_{\beta}\right), 127.4,103.1$ $\left(\mathrm{C}_{\beta}\right), 102.0\left(\mathrm{C}^{\mathrm{D}}\right), 101.1\left(\mathrm{C}^{\mathrm{B}}\right), 100.9\left(\mathrm{C}_{\beta}\right), 99.9\left(\mathrm{C}^{\mathrm{E}}\right), 99.6\left(\mathrm{C}_{\beta}\right), 99.5(\times 2$, $\left.\mathrm{C} 1^{\mathrm{A}}, \mathrm{C}^{\mathrm{C}}\right), 99.4\left(\mathrm{C}_{\beta}\right), 97.6\left(\mathrm{C} 1^{\mathrm{F}}, \mathrm{J}_{\mathrm{C}-\mathrm{H}}=173 \mathrm{~Hz}\right), 83.6\left(\mathrm{C}_{\beta}\right), 81.7\left(\mathrm{C} 4^{\mathrm{F}}\right)$, $80.6\left(\mathrm{C}^{\mathrm{F}}\right), 79.1\left(\mathrm{C}^{\mathrm{F}}\right), 76.8\left(\mathrm{C}^{\mathrm{D}}\right), 76.6\left(\mathrm{C}^{\mathrm{D}}\right), 76.1\left(\mathrm{C} 4^{\mathrm{A}}\right), 76.1\left(\mathrm{C}_{\beta}\right), 75.7$ $(\mathrm{Bn}), 75.5\left(\mathrm{C}_{\beta}\right), 75.4\left(\mathrm{C}_{\beta}\right), 75.1\left(\mathrm{C}_{\beta}\right), 75.1\left(\mathrm{C}_{\beta}\right), 74.8\left(\mathrm{C}_{\beta}\right), 74.5\left(\mathrm{C}_{\beta}\right), 74.2$ $\left(\mathrm{C} 4^{\mathrm{B}}\right), 74.1\left(\mathrm{C}_{\beta}\right), 73.7\left(\mathrm{C}^{\mathrm{D}}\right), 73.5(\mathrm{Bn}), 73.5\left(\mathrm{C}^{\mathrm{C}}\right), 72.6\left(\mathrm{C}_{\beta}\right), 72.4\left(\mathrm{C}^{\mathrm{A}}\right)$, $72.3\left(\mathrm{C}_{\beta}\right), 71.8\left(\mathrm{C}^{\mathrm{B}}\right), 71.5\left(\mathrm{C}_{\beta}\right), 71.4,71.2,71.2\left(\mathrm{C}^{\mathrm{A}}, \mathrm{C} 2^{\mathrm{B}}, \mathrm{C} 3^{\mathrm{C}}\right), 71.1$ $\left(\mathrm{C}_{\beta}\right), 70.6,70.5\left(\mathrm{C} 2^{\mathrm{C}}, \mathrm{C}^{\mathrm{E}}\right), 70.4(\mathrm{Bn}), 70.3\left(\mathrm{C} 5^{\mathrm{F}}\right), 70.2\left(\mathrm{C}_{\beta}\right), 69.8\left(\mathrm{C}^{\mathrm{E}}\right)$, $68.7\left(\mathrm{C} 4^{\mathrm{E}}\right), 62.9,62.8\left(\mathrm{C}^{\mathrm{A}}, \mathrm{C}^{\mathrm{D}}\right), 62.7\left(\mathrm{C}_{\beta}\right), 62.0\left(\mathrm{C}^{\mathrm{B}}\right), 61.5\left(\mathrm{C} 5^{\mathrm{C}}\right), 60.9$ $\left(\mathrm{C}^{\mathrm{E}}\right), 60.7\left(\mathrm{C}_{\beta}\right), 60.1(\mathrm{OMe}), 52.7\left(\mathrm{C}_{\beta}\right), 52.2(\mathrm{COOMe})$. HRMS: calcd. for $\mathrm{C}_{124} \mathrm{H}_{112} \mathrm{O}_{37} \mathrm{Na}[\mathrm{M}+\mathrm{Na}]^{+} 2215.6775$; found 2215.6758 .

$\beta$-D-Xylopyranosyl-( $1 \rightarrow 4)$-[D-glucopyranosyluronic acid-( $1 \rightarrow 2)]-\beta$-Dxylopyranosyl-( $1 \rightarrow 4)-\beta$-D-xylopyranosyl-( $1 \rightarrow 4)-\beta$-D-xylopyranosyl-

$(1 \rightarrow 4)$-D-xylopyranose (1): General procedure C: Fully protected hexasaccharide $18(47.8 \mathrm{mg}, 0.021 \mathrm{mmol})$. Reaction time $5.5 \mathrm{~h}$. TLC eluent for deprotection of methyl ester heptane/toluene/acetone 2:1:2. Reaction time for deprotection of benzoyl groups overnight with TLC eluent EtOAc/MeOH/ $\mathrm{H}_{2} \mathrm{O} /$ acetic acid 6:3:0.8:0.2. The product benzyl $\beta$-Dxylopyranosyl-( $1 \rightarrow 4)$-[2,3,4-tri-O-benzyl-D-glucopyranosyluronic acid$(1 \rightarrow 2)]-\beta$-D-xylopyranosyl-( $1 \rightarrow 4)-\beta$-D-xylopyranosyl-( $1 \rightarrow 4)-\beta$-Dxylopyranosyl-( $(\rightarrow 4)-\beta$-D-xylopyranoside $(18.9 \mathrm{mg}, 74 \%)$ was obtained as an inseparable $\alpha / \beta$ mixture. $R_{\mathrm{f}}(\boldsymbol{\alpha})=0.50\left(\mathrm{EtOAc} / \mathrm{MeOH} / \mathrm{H}_{2} \mathrm{O} /\right.$ acetic acid 6:3:0.8:0.2). $R \mathrm{f}(\boldsymbol{\beta})=0.65\left(\mathrm{EtOAc} / \mathrm{MeOH} / \mathrm{H}_{2} \mathrm{O} /\right.$ acetic acid 6:3:0.8:0.2) For the $\alpha$-glucuronide (including partial NMR data for the $\beta$-isomer): ${ }^{1} \mathrm{H}$ NMR $\left(800 \mathrm{MHz}, \mathrm{D}_{2} \mathrm{O}\right): \delta=7.49-7.39(\mathrm{~m}, 22 \mathrm{H}), 5.50(\mathrm{~d}, J=3.2 \mathrm{~Hz}, 1 \mathrm{H}$, $\left.\mathrm{H} 1^{\mathrm{F}}\right), 4.92-4.90(\mathrm{~m}, 1 \mathrm{H}, \mathrm{Bn}), 4.88-4.72(\mathrm{~m}, 7 \mathrm{H}, \mathrm{Bn}), 4.66(\mathrm{~d}, J=10.5 \mathrm{~Hz}$, $1 \mathrm{H}), 4.60\left(\mathrm{~d}, J=7.4 \mathrm{~Hz}, 1 \mathrm{H}, \mathrm{H} 1^{\mathrm{D}}\right), 4.53\left(\mathrm{~d}, J=7.7 \mathrm{~Hz}, 1 \mathrm{H}, \mathrm{H} 1^{\mathrm{A}}\right), 4.49$ $4.46\left(\mathrm{~m}, 3 \mathrm{H}, \mathrm{H} 1^{\mathrm{B}}, \mathrm{H} 1^{\mathrm{E}}, \mathrm{H} 5^{\mathrm{F}}\right), 4.12$ (dd, $\left.J=11.8,5.2 \mathrm{~Hz}, 2 \mathrm{H}, \mathrm{H} 5^{\mathrm{A}}, \mathrm{H} 5^{\mathrm{D}}\right)$, 4.03 (dd, $J=11.8,5.2 \mathrm{~Hz}, 1 \mathrm{H}, \mathrm{H} 5^{\mathrm{B}}$ ), 4.01-3.98 (m, 3H, H1 ${ }^{\mathrm{C}}, \mathrm{H} 5^{\mathrm{E}}, \mathrm{H} 3^{\mathrm{F}}$ ), $3.90\left(\mathrm{dd}, J=11.7,5.2 \mathrm{~Hz}, 1 \mathrm{H}, \mathrm{H} 5^{\mathrm{C}}\right), 3.85-3.80\left(\mathrm{~m}, 3 \mathrm{H}, \mathrm{H} 4^{\mathrm{A}}, \mathrm{H} 4^{\mathrm{D}}\right), 3.76$ (dd, $J=9.8,3.3 \mathrm{~Hz}, 1 \mathrm{H}, \mathrm{H} 2^{\mathrm{F}}$ ), 3.75-3.72 (m, 2H, H4, $\mathrm{H}^{\mathrm{F}}$ ), 3.70 (d, $J=$ $\left.9.2 \mathrm{~Hz}, 1 \mathrm{H}, \mathrm{H} 3^{\mathrm{D}}\right), 3.65-3.62\left(\mathrm{~m}, 2 \mathrm{H}, \mathrm{H} 4^{\mathrm{E}}\right), 3.59-3.52\left(\mathrm{~m}, 5 \mathrm{H}, \mathrm{H}^{\mathrm{A}}, \mathrm{H}^{\mathrm{B}}\right.$, $\left.\mathrm{H} 4^{\mathrm{B}}, \mathrm{H} 2^{\mathrm{D}}\right), 3.46-3.39\left(\mathrm{~m}, 5 \mathrm{H}, \mathrm{H} 5^{\circ} \mathrm{A}, \mathrm{H} 3^{\mathrm{C}}, \mathrm{H} 5^{\circ}, \mathrm{H} 3^{\mathrm{E}}\right), 3.37-3.32(\mathrm{~m}, 4 \mathrm{H}$, $\left.\mathrm{H} 2^{\mathrm{A}}, \mathrm{H} 5^{\mathrm{B}}\right), 3.31-3.27\left(\mathrm{~m}, 3 \mathrm{H}, \mathrm{H} 2^{\mathrm{B}}, \mathrm{H} 2^{\mathrm{E}}, \mathrm{H} 5^{\mathrm{E}}\right), 3.21-3.19\left(\mathrm{~m}, 1 \mathrm{H}, \mathrm{H} 2^{\mathrm{C}}\right)$, 3.03 (t, $\left.J=11.2 \mathrm{~Hz}, 1 \mathrm{H}, \mathrm{H}^{\prime} \mathrm{C}\right) .{ }^{13} \mathrm{C}$ NMR $\left(201 \mathrm{MHz}, \mathrm{D}_{2} \mathrm{O}\right): \delta=176.3$, $137.6,137.2,137.0,136.5,129.0,128.8,128.7,128.7,128.7,128.5$, 128.4, 128.3, 128.2, 127.7, 102.0 (C1E), 101.9 $\left(\mathrm{C} 1^{\mathrm{A}}\right), 101.7,101.7\left(\mathrm{C} 1^{\mathrm{B}}\right)$, 101.6, 101.3 (C1 $\left.{ }^{\mathrm{C}}\right), 100.5\left(\mathrm{C} 1^{\mathrm{D}}\right), 96.1\left(\mathrm{C} 1^{\mathrm{F}}\right), 80.5\left(\mathrm{C} 4^{\mathrm{F}}\right), 80.4\left(\mathrm{C} 3^{\mathrm{F}}\right), 79.5$ $\left(\mathrm{C} 2^{\mathrm{F}}\right), 76.8,76.7\left(\mathrm{C} 2^{\mathrm{D}}, \mathrm{C} 4^{\mathrm{D}}\right), 76.5,76.4\left(\mathrm{C} 4^{\mathrm{A}}\right), 76.4,76.0,75.9\left(\mathrm{C} 4^{\mathrm{B}}, \mathrm{Bn}\right)$, $75.6\left(\mathrm{C}^{\mathrm{E}}\right), 74.9(\mathrm{Bn}), 74.8\left(\mathrm{C} 4^{\mathrm{C}}\right), 73.9(\mathrm{Bn}), 73.8\left(\mathrm{C}^{\mathrm{A}}\right), 73.5\left(\mathrm{C} 3^{\mathrm{C}}\right), 73.4$ $\left(\mathrm{C} 3^{\mathrm{B}}\right), 72.9,72.9\left(\mathrm{C}^{\mathrm{A}}, \mathrm{C} 5^{\mathrm{F}}\right), 72.9,72.8\left(\mathrm{C} 2^{\mathrm{B}}, \mathrm{C} 2^{\mathrm{E}}\right), 72.6\left(\mathrm{C}^{\mathrm{C}}\right), 72.4$ (C3) $\left.3^{\mathrm{D}}\right), 71.6(\mathrm{Bn}), 69.2\left(\mathrm{C}^{\mathrm{E}}\right), 65.2\left(\mathrm{C}^{\mathrm{E}}\right), 62.9,62.8,62.8\left(\mathrm{C}^{\mathrm{A}}, \mathrm{C}^{\mathrm{B}}, \mathrm{C} 5^{\mathrm{D}}\right)$, $62.7\left(\mathrm{C}^{\mathrm{C}}\right)$. HRMS: calcd. for $\mathrm{C}_{59} \mathrm{H}_{74} \mathrm{O}_{27} \mathrm{Na}[\mathrm{M}+\mathrm{Na}]^{+}$1237.4310; found 1237.4318. The above benzyl glycoside $(17.1 \mathrm{mg}, 0.014 \mathrm{mmol})$ was dissolved in EtOAc/EtOH/ $\mathrm{H}_{2} \mathrm{O}$ 1:1:1 (2.25 mL) and $\mathrm{Pd} / \mathrm{C}$ Degussa type $(8.3 \mathrm{mg}, 0.077 \mathrm{mmol})$ was added. The mixture was stirred under an atm. of $\mathrm{H}_{2}$ overnight. The reaction was then filtered over a syringe filter $(0.45$ $\mu \mathrm{m})$ and conc. in vacuo to afford product $1(11.3 \mathrm{mg}, 94 \%) . R_{\mathrm{f}}=0.11$ (EtOAc/MeOH/ $/ \mathrm{H}_{2} \mathrm{O} /$ acetic acid 6:3:0.8:0.2). For the $\alpha$-glucuronide (including partial NMR data for the $\beta$-isomer): ${ }^{1} \mathrm{H}$ NMR $\left(800 \mathrm{MHz}, \mathrm{D}_{2} \mathrm{O}\right):$ $=5.32(\mathrm{~d}, J=3.9 \mathrm{~Hz}, 1 \mathrm{H}, \mathrm{H} 1 \mathrm{~F}), 5.20\left(\mathrm{~d}, J=3.6 \mathrm{~Hz}, 0.62 \mathrm{H}, \mathrm{H} 1 \mathrm{a}^{\mathrm{A}}\right), 4.71(\mathrm{~d}$, $J=6.8 \mathrm{~Hz}, 0.30 \mathrm{H}), 4.69(\mathrm{~d}, J=7.9 \mathrm{~Hz}, 0.33 \mathrm{H}), 4.66(\mathrm{~d}, J=7.5 \mathrm{~Hz}, 1 \mathrm{H}$, $\left.\mathrm{H} 1^{\mathrm{D}}\right), 4.60\left(\mathrm{~d}, J=7.9 \mathrm{~Hz}, 1 \mathrm{H}, \mathrm{H} 1^{\mathrm{A}}\right), 4.50-4.47\left(\mathrm{~m}, 5 \mathrm{H}, \mathrm{H} 1^{\mathrm{B}}, \mathrm{H} 1^{\mathrm{C}}, \mathrm{H} 1^{\mathrm{E}}\right)$, $4.38\left(\mathrm{~d}, J=10.2 \mathrm{~Hz}, 1 \mathrm{H}, \mathrm{H} 5^{\mathrm{F}}\right.$ ), 4.17 (dd, $J=11.8,5.2 \mathrm{~Hz}, 1 \mathrm{H}, \mathrm{H} 5^{\mathrm{C}}$ ), 4.15-4.10 (m, 4H, H5 $\left.5^{\mathrm{B}}, \mathrm{H} 5^{\mathrm{D}}\right), 4.07\left(\mathrm{dd}, J=11.8,5.3 \mathrm{~Hz}, 1 \mathrm{H}, \mathrm{H} 5_{\beta^{\mathrm{A}}}\right), 3.99$ (dd, $J=11.7,5.5 \mathrm{~Hz}, 2 \mathrm{H}, \mathrm{H}^{\mathrm{E}}$ ), 3.85-3.75 (m, $11 \mathrm{H}, \mathrm{H} 3 \mathrm{a}^{\mathrm{A}}, \mathrm{H} 4 \mathrm{a}^{\mathrm{A}}, \mathrm{H} 5 \mathrm{a}^{\mathrm{A}}$, $\left.\mathrm{H}^{\prime}{ }^{{ }^{A}}, \mathrm{H}_{\beta^{A}}{ }^{\mathrm{A}}, \mathrm{H} 4^{\mathrm{B}}, \mathrm{H} 4^{\mathrm{C}}, \mathrm{H} 4^{\mathrm{D}}, \mathrm{H} 3^{\mathrm{F}}\right), 3.71-3.70(\mathrm{~m}, 0.48 \mathrm{H}), 3.66-3.62(\mathrm{~m}$,
4H, $\mathrm{H}^{\mathrm{D}}, \mathrm{H} 4^{\mathrm{E}}$ ), 3.61-3.55 (m, 7H, H2 $\left.{ }^{\mathrm{A}}, \mathrm{H}{ }^{\mathrm{A}}, \mathrm{H}^{\mathrm{B}}, \mathrm{H} 3^{\mathrm{C}}, \mathrm{H} 2^{\mathrm{F}}\right), 3.53$ (dd, J $=6.9,2.6 \mathrm{~Hz}, 0.88 \mathrm{H}), 3.51-3.48\left(\mathrm{~m}, 3 \mathrm{H}, \mathrm{H} 2^{\mathrm{D}}, \mathrm{H} 4 \mathrm{~F}\right), 3.46-3.38(\mathrm{~m}, 8 \mathrm{H}$, $\left.\mathrm{H} 5^{\prime} \beta^{\mathrm{A}}, \mathrm{H} 5^{\mathrm{B}}, \mathrm{H} 5^{\circ}, \mathrm{H} 5^{\mathrm{D}}, \mathrm{H} 3^{\mathrm{E}}\right), 3.33-3.26\left(\mathrm{~m}, 8 \mathrm{H}, \mathrm{H} 2 \beta^{\mathrm{A}}, \mathrm{H} 2^{\mathrm{B}}, \mathrm{H} 2^{\mathrm{C}}, \mathrm{H} 2^{\mathrm{E}}\right.$, $\left.\mathrm{H} 5^{E}\right) .{ }^{13} \mathrm{C}$ NMR $\left(201 \mathrm{MHz}, \mathrm{D}_{2} \mathrm{O}\right): \delta=177.0,102.0,101.6(\times 2)\left(\mathrm{C} 1^{\mathrm{B}}, \mathrm{C}^{\mathrm{C}}\right.$, $\left.\mathrm{C} 1^{\mathrm{E}}\right), 101.3\left(\mathrm{C} 1^{\mathrm{D}}\right), 97.6\left(\mathrm{C} 1^{\mathrm{F}}\right), 96.5\left(\mathrm{C} 1_{\beta}{ }^{\mathrm{A}}\right), 92.0\left(\mathrm{C} 1^{\mathrm{A}}\right), 76.8\left(\mathrm{C} 4^{\mathrm{D}}\right), 76.5$, $76.5,76.4,76.3\left(\mathrm{C} 4 \alpha^{\mathrm{A}}, \mathrm{C} 4_{\beta^{\mathrm{A}}}, \mathrm{C} 4^{\mathrm{B}}, \mathrm{C} 2^{\mathrm{D}}\right), 75.9\left(\mathrm{C} 4^{\mathrm{C}}\right), 75.6\left(\mathrm{C} 3^{\mathrm{E}}\right), 75.3\left(\mathrm{C}_{\beta}\right)$, $74.0\left(\mathrm{C}_{\beta}{ }^{\mathrm{A}}\right), 73.9\left(\mathrm{C}_{\beta^{\mathrm{A}}}{ }^{\mathrm{A}}\right), 73.8\left(\mathrm{C}_{\beta}\right), 73.7,73.6\left(\mathrm{C}^{\mathrm{B}}, \mathrm{C}^{\mathrm{C}}\right), 73.6\left(\mathrm{C}_{\beta}\right), 72.8$, $72.7\left(\mathrm{C}_{\beta}\right), 72.7,72.6,72.6\left(\mathrm{C}^{\mathrm{B}}, \mathrm{C2}^{\mathrm{C}}, \mathrm{C}^{\mathrm{E}}, \mathrm{C}^{\mathrm{F}}\right), 72.4\left(\mathrm{C}^{\mathrm{D}}\right), 72.1,72.0$

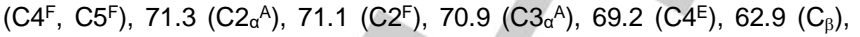
$65.2\left(\mathrm{C} 5^{\mathrm{E}}\right), 63.0,62.9,62.8,62.8\left(\mathrm{C1}_{\beta}{ }^{\mathrm{A}}, \mathrm{C} 5^{\mathrm{B}}, \mathrm{C} 5^{\mathrm{C}}, \mathrm{C} 5^{\mathrm{D}}\right), 58.8\left(\mathrm{C} 5^{\mathrm{A}}\right)$. HRMS: calcd. for $\mathrm{C}_{31} \mathrm{H}_{50} \mathrm{O}_{27} \mathrm{Na}[\mathrm{M}+\mathrm{Na}]^{+}$877.2432; found 877.2443.

\section{$\beta$-D-Xylopyranosyl-(1 $\rightarrow 4)$-[4-O-methyl-D-glucopyranosyluronic acid-} $(1 \rightarrow 2)]-\beta$-D-xylopyranosyl-( $1 \rightarrow 4)-\beta$-D-xylopyranosyl-( $1 \rightarrow 4)-\beta$-D-

xylopyranosyl-(1 $\rightarrow 4)$-D-xylopyranose $(2)$ : General procedure C: Fully protected hexasaccharide $19(17.9 \mathrm{mg}, 0.008 \mathrm{mmol})$. Reaction time $4 \mathrm{~h}$. TLC eluent for deprotection of methyl ester heptane/toluene/acetone 2:1:2. Reaction time for deprotection of benzoyl groups overnight with TLC eluent for $\mathrm{EtOAc} / \mathrm{MeOH} / \mathrm{H}_{2} \mathrm{O} /$ acetic acid 6:3:0.8:0.2. The product benzyl $\quad \beta$-D-xylopyranosyl-(1 $\rightarrow 4)$-[2,3-di-O-benzyl-4-O-methyl-Dglucopyranosyluronic acid- $(1 \rightarrow 2)]-\beta$-D-xylopyranosyl-( $(1 \rightarrow 4)-\beta$-Dxylopyranosyl-( $1 \rightarrow 4)-\beta$-D-xylopyranosyl-( $1 \rightarrow 4)-\beta$-D-xylopyranoside was obtained as an inseparable $\alpha / \beta$ mixture $(8.6 \mathrm{mg}, 93 \%) . R_{\mathrm{f}}(\boldsymbol{\alpha})=0.42$ $\left(\mathrm{EtOAc} / \mathrm{MeOH} / \mathrm{H}_{2} \mathrm{O} /\right.$ acetic acid 6:3:0.8:0.2). $R_{\mathrm{i}}(\boldsymbol{\beta})=0.55$ $\left(\mathrm{EtOAc} / \mathrm{MeOH} / \mathrm{H}_{2} \mathrm{O} /\right.$ acetic acid 6:3:0.8:0.2). For the $\alpha$-glucuronide (including partial NMR data for the $\beta$-isomer): ${ }^{1} \mathrm{H} \mathrm{NMR}\left(800 \mathrm{MHz}, \mathrm{D}_{2} \mathrm{O}\right): \delta$ $=7.50-7.39(\mathrm{~m}, 30 \mathrm{H}), 5.48\left(\mathrm{~d}, J=3.5 \mathrm{~Hz}, 1 \mathrm{H}, \mathrm{H}^{\mathrm{F}}\right), 5.03(\mathrm{~d}, J=10.9 \mathrm{~Hz}$, $0.5 \mathrm{H}), 4.92-4.90(\mathrm{~m}, 2 \mathrm{H}, \mathrm{Bn}), 4.90-4.82(\mathrm{~m}, 5 \mathrm{H}, \mathrm{Bn}), 4.77-4.74(\mathrm{~m}, 3 \mathrm{H}$, $\mathrm{Bn}), 4.60\left(\mathrm{~d}, J=7.5 \mathrm{~Hz}, 1 \mathrm{H}, \mathrm{H} 1^{\mathrm{D}}\right), 4.54-4.52\left(\mathrm{~m}, 2 \mathrm{H}, \mathrm{H} 1^{\mathrm{A}}\right), 4.51-4.45(\mathrm{~m}$, $\left.4 \mathrm{H}, \mathrm{H}^{\mathrm{B}}, \mathrm{H} 1^{\mathrm{E}}\right), 4.41\left(\mathrm{~d}, J=9.9 \mathrm{~Hz}, 1 \mathrm{H}, \mathrm{H} 5^{\mathrm{F}}\right), 4.16-4.14(\mathrm{~m}, 1 \mathrm{H}), 4.13-$ $4.11\left(\mathrm{~m}, 3 \mathrm{H}, \mathrm{H} 5^{\mathrm{A}}, \mathrm{H} 5^{\mathrm{D}}\right), 4.04\left(\mathrm{dd}, J=11.9,5.0 \mathrm{~Hz}, 1 \mathrm{H}, \mathrm{H} 5^{\mathrm{B}}\right), 4.01(\mathrm{~d}, J=$ $\left.7.4 \mathrm{~Hz}, \mathrm{H} 1^{\mathrm{C}}\right)$, 3.99-3.97 (m, 2H, H5 $\left.5^{\mathrm{E}}, \mathrm{H} 3^{\mathrm{F}}\right), 3.91-3.87\left(\mathrm{~m}, 2 \mathrm{H}, \mathrm{H} 5^{\mathrm{C}}\right)$, 3.84-3.79 (m, 4H, H4 $\left.4^{\mathrm{A}}, \mathrm{H} 4^{\mathrm{D}}\right), 3.75-3.71\left(\mathrm{~m}, 3 \mathrm{H}, \mathrm{H}^{\mathrm{C}}, \mathrm{H}^{\mathrm{F}}\right), 3.70-3.67(\mathrm{~m}$, $\left.2 \mathrm{H}, \mathrm{H} 3^{\mathrm{D}}\right), 3.66-3.63\left(\mathrm{~m}, 2 \mathrm{H}, \mathrm{H}^{\mathrm{E}}\right), 3.62-3.51\left(\mathrm{~m}, 14 \mathrm{H}, \mathrm{H}^{\mathrm{A}}, \mathrm{H}^{\mathrm{B}}, \mathrm{H}^{\mathrm{B}}\right.$, $\left.\mathrm{H} 2^{\mathrm{D}}\right), 3.46-3.26\left(\mathrm{~m}, 19 \mathrm{H}, \mathrm{H}^{\mathrm{A}}, \mathrm{H} 5^{\mathrm{A}}, \mathrm{H} 2^{\mathrm{B}}, \mathrm{H} 5^{\mathrm{B}}, \mathrm{H} 3^{\mathrm{C}}, \mathrm{H} 5^{\mathrm{D}}, \mathrm{H} 2^{\mathrm{E}}, \mathrm{H} 3^{\mathrm{E}}, \mathrm{H} 5^{\circ}\right.$, $\mathrm{H} 4 \mathrm{~F}, \mathrm{OMe}), 3.32-3.19(\mathrm{~m}, 2 \mathrm{H}, \mathrm{H} 2 \mathrm{C}), 3.02\left(\mathrm{t}, J=11.1 \mathrm{~Hz}, 1 \mathrm{H}, \mathrm{H} 5^{\circ} \mathrm{C}\right) .{ }^{13} \mathrm{C}$ NMR $\left(201 \mathrm{MHz}, \mathrm{D}_{2} \mathrm{O}\right): \delta=176.6,137.8,137.4,136.7,129.1,129.1$, $129.0,128.9,128.9,128.8,128.8,128.6,128.4,127.9,102.9,102.3$, 102.1, 101.8 (C1 $\left.{ }^{\mathrm{A}}, \mathrm{C} 1^{\mathrm{B}}, \mathrm{C} 1^{\mathrm{E}}\right), 101.8,101.7,101.5\left(\mathrm{C} 1^{\mathrm{C}}\right), 100.7\left(\mathrm{C} 1^{\mathrm{D}}\right)$, 99.5, 96.2 (C1F), 83.1, 82.7 (C4F), 82.5, 81.3, 80.6 (C3F), 79.5, 79.3 (C2F), $77.0\left(\mathrm{C}^{\mathrm{D}}\right), 76.7\left(\mathrm{C}^{\mathrm{D}}\right), 76.6\left(\mathrm{C}^{\mathrm{A}}\right), 76.5,76.4,76.2,76.2\left(\mathrm{C} 4^{\mathrm{B}}\right), 76.0$, $76.0(\mathrm{Bn}), 75.8,75.7\left(\mathrm{C} 3^{\mathrm{E}}\right), 75.7,75.6,75.3,74.9\left(\mathrm{C} 4^{\mathrm{C}}\right), 74.1(\mathrm{Bn}), 74.0$ $\left(\mathrm{C} 3^{\mathrm{A}}\right), 73.9,73.8,73.8,73.7\left(\mathrm{C}^{\mathrm{C}}\right), 73.6\left(\mathrm{C} 3^{\mathrm{B}}\right), 73.1,73.0\left(\mathrm{C} 2^{\mathrm{A}}, \mathrm{C} 2^{\mathrm{E}}\right)$, 72.9, 72.8, $72.8\left(\mathrm{C} 2^{\mathrm{C}}\right), 72.7,72.6,72.6\left(\mathrm{C}^{\mathrm{B}}, \mathrm{C} 3^{\mathrm{D}}, \mathrm{C} 5^{\mathrm{F}}\right), 71.8(\mathrm{Bn}), 69.3$ $\left(\mathrm{C} 4^{\mathrm{E}}\right), 69.2,65.4\left(\mathrm{C} 5^{\mathrm{E}}\right), 65.3,63.1,63.1,63.0\left(\mathrm{C}^{\mathrm{A}}, \mathrm{C} 5^{\mathrm{B}}, \mathrm{C}^{\mathrm{D}}\right), 62.8$ (C5) $60.3(\mathrm{OMe}), 60.3$. HRMS: calcd. for $\mathrm{C}_{53} \mathrm{H}_{70} \mathrm{O}_{27} \mathrm{Na}\left[\mathrm{M}+\mathrm{Na}^{+}\right.$ 1161.3997; found 1164.4005. The above glycoside (21.2 mg, 0.019 $\mathrm{mmol}$ ) was dissolved in $\mathrm{EtOAc} / \mathrm{EtOH} / \mathrm{H}_{2} \mathrm{O}$ 1:1:1 (2.25 mL) and $\mathrm{Pd} / \mathrm{C}$ Degussa type $(10.4 \mathrm{mg}, 0.098 \mathrm{mmol})$ was added. The mixture was stirred under an atm. of $\mathrm{H}_{2}$ overnight. The reaction was then filtered over a syringe filter $(0.45 \mu \mathrm{m})$ and conc. in vacuo to afford product $2(15.0 \mathrm{mg}$, $93 \%) . R_{f}=0.27\left(\mathrm{EtOAc} / \mathrm{MeOH} / \mathrm{H}_{2} \mathrm{O} /\right.$ acetic acid 6:3:0.8:0.2). $\alpha: \beta$ ratio approximately $0.6: 1$. For the $\alpha$-glucuronide (including partial NMR data for the $\beta$-isomer): ${ }^{1} \mathrm{H}$ NMR $\left(800 \mathrm{MHz}, \mathrm{D}_{2} \mathrm{O}\right): \delta=5.31(\mathrm{~d}, J=3.5 \mathrm{~Hz}, 0.18)$, $5.29\left(\mathrm{~d}, J=3.7 \mathrm{~Hz}, 1 \mathrm{H}, \mathrm{H} 1^{\mathrm{F}}\right), 5.19\left(\mathrm{~d}, J=3.5 \mathrm{~Hz}, 0.62 \mathrm{H}, \mathrm{H} 1_{\mathrm{a}}{ }^{\mathrm{A}}\right), 4.68(\mathrm{~d}, J$ $=6.8 \mathrm{~Hz}, 0.22 \mathrm{H}), 4.63\left(\mathrm{~d}, J=7.6 \mathrm{~Hz}, 1 \mathrm{H}, \mathrm{H} 1^{\mathrm{D}}\right), 4.61(\mathrm{~d}, J=7.9 \mathrm{~Hz}$, $0.38 \mathrm{H}), 4.59\left(\mathrm{~d}, J=7.9 \mathrm{~Hz}, 1 \mathrm{H}, \mathrm{H}_{\beta^{\mathrm{A}}}^{\mathrm{A}}\right), 4.49-4.46\left(\mathrm{~m}, 5 \mathrm{H}, \mathrm{H} 1^{\mathrm{B}}, \mathrm{H} 1^{\mathrm{C}}, \mathrm{H} 1^{\mathrm{E}}\right)$, $4.33\left(\mathrm{~d}, J=10.1 \mathrm{~Hz}, 1 \mathrm{H}, \mathrm{H} 5^{\mathrm{F}}\right), 4.15\left(\mathrm{dd}, J=11.9,5.2 \mathrm{~Hz}, 1 \mathrm{H}, \mathrm{H} 5^{\mathrm{C}}\right.$ ), 4.12-4.10 (m, 4H, H5 $\left.5^{\mathrm{B}}, \mathrm{H} 5^{\mathrm{D}}\right), 4.06\left(\mathrm{dd}, J=11.7,5.2 \mathrm{~Hz}, 1 \mathrm{H}, \mathrm{H} 5^{\mathrm{A}}{ }^{\mathrm{A}}\right), 3.99-$ $3.96\left(\mathrm{~m}, 2 \mathrm{H}, \mathrm{H} 5^{\mathrm{E}}\right), 3.86-3.73\left(\mathrm{~m}, 12 \mathrm{H}, \mathrm{H} 3 \mathrm{a}^{\mathrm{A}}, \mathrm{H} 4 \mathrm{\alpha}^{\mathrm{A}}, \mathrm{H} 5 \mathrm{a}^{\mathrm{A}}, \mathrm{H} 5^{\prime} \mathrm{a}^{\mathrm{A}}, \mathrm{H} 4 \beta^{\mathrm{A}}, \mathrm{H} 4^{\mathrm{B}}\right.$, $\left.\mathrm{H}^{\mathrm{C}}, \mathrm{H}^{\mathrm{D}}, \mathrm{H} 3^{\mathrm{F}}\right), 3.67$ (d, $\left.J=9.7 \mathrm{~Hz}, 0.69 \mathrm{H}\right), 3.64-3.61\left(\mathrm{~m}, 4 \mathrm{H}, \mathrm{H} 3^{\mathrm{D}}, \mathrm{H} 4^{\mathrm{E}}\right)$, 3.59-3.51 (m, 8H, $\left.\mathrm{H}_{2}{ }^{\mathrm{A}}, \mathrm{H}{ }^{\mathrm{A}}, \mathrm{H}^{\mathrm{B}}, \mathrm{H}^{\mathrm{C}}, \mathrm{H}^{\mathrm{F}}\right), 3.49-3.42\left(\mathrm{~m}, 11 \mathrm{H}, \mathrm{H} 5^{\circ} \mathrm{C}\right.$, $\left.\mathrm{H} 2^{\mathrm{D}}, \mathrm{H}^{\mathrm{E}}, \mathrm{OCH}_{3}\right), 3.40-3.36\left(\mathrm{~m}, 5 \mathrm{H}, \mathrm{H} 5^{\prime}{ }^{\mathrm{A}}, \mathrm{H}^{\mathrm{B}}, \mathrm{H} 5^{\mathrm{D}}\right), 3.33-3.21$ ( $\mathrm{m}$, $\left.10 \mathrm{H}, \mathrm{H} 2 \beta^{\mathrm{A}}, \mathrm{H} 2^{\mathrm{B}}, \mathrm{H} 2^{\mathrm{C}}, \mathrm{H}^{\mathrm{E}}, \mathrm{H} 5^{\mathrm{E}}, \mathrm{H} 4^{\mathrm{F}}\right) .{ }^{13} \mathrm{C}$ NMR $\left(201 \mathrm{MHz}, \mathrm{D}_{2} \mathrm{O}\right): \delta=$ 176.8, 103.5 $\left(\mathrm{C}_{\beta}\right), 102.0\left(\mathrm{C} 1^{\mathrm{E}}\right), 101.9\left(\mathrm{C}_{\beta}\right), 101.6(\times 2)\left(\mathrm{C} 1^{\mathrm{B}}, \mathrm{C} 1^{\mathrm{C}}\right), 101.5$ $\left(\mathrm{C}_{\beta}\right), 101.3\left(\mathrm{C}^{\mathrm{D}}\right)$, $99.8\left(\mathrm{C}_{\beta}\right), 97.5\left(\mathrm{C}^{\mathrm{F}}\right), 96.5\left(\mathrm{C}{ }_{\beta}{ }^{\mathrm{A}}\right), 92.0\left(\mathrm{C}_{1}{ }^{\mathrm{A}}\right), 82.4$ $\left(\mathrm{C} 4^{\mathrm{F}}\right), 82.2\left(\mathrm{C}_{\beta}\right), 81.7\left(\mathrm{C}_{\beta}\right), 76.8\left(\mathrm{C} 4^{\mathrm{D}}\right), 76.5\left(\mathrm{C}_{\beta}\right), 76.5,76.4,76.4,76.3$ $\left(\mathrm{C} 4{ }^{\mathrm{A}}, \mathrm{C} 4_{\beta^{\mathrm{A}}}, \mathrm{C} 4^{\mathrm{B}}, \mathrm{C} 2^{\mathrm{D}}\right), 75.9\left(\mathrm{C} 4^{\mathrm{C}}\right), 75.6\left(\mathrm{C} 3^{\mathrm{E}}\right), 75.5\left(\mathrm{C}_{\beta}\right), 74.7\left(\mathrm{C}_{\beta}\right), 74.0$, $73.9\left(\mathrm{C} 2_{\beta}{ }^{\mathrm{A}}, \mathrm{C}_{\beta}{ }^{\mathrm{A}}\right), 73.8\left(\mathrm{C}_{\beta}\right), 73.6,73.6\left(\mathrm{C}^{\mathrm{B}}, \mathrm{C}^{\mathrm{C}}\right), 73.6\left(\mathrm{C}_{\beta}\right), 72.8\left(\mathrm{C}_{\beta}\right)$, 
$72.8\left(\mathrm{C}^{\mathrm{E}}\right), 72.7\left(\mathrm{C}_{\beta}\right), 72.7,72.6\left(\mathrm{C}^{\mathrm{B}}, \mathrm{C}^{\mathrm{C}}\right), 72.3\left(\mathrm{C} 3^{\mathrm{D}}\right), 72.2,72.1\left(\mathrm{C} 3^{\mathrm{F}}\right.$,

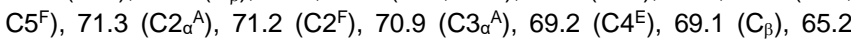
(C5 $\left.{ }^{\mathrm{E}}\right), 62.9,62.9,62.8(\times 2)\left(\mathrm{C}_{\beta^{\mathrm{A}}}{ }^{\mathrm{A}}, \mathrm{C}^{\mathrm{B}}, \mathrm{C}^{\mathrm{C}}, \mathrm{C}^{\mathrm{D}}\right), 59.8(\mathrm{OMe}), 58.8$ $\left(\mathrm{C}_{a}{ }^{A}\right)$. HRMS: calcd. for $\mathrm{C}_{32} \mathrm{H}_{52} \mathrm{O}_{27} \mathrm{Na}\left[\mathrm{M}+\mathrm{Na}^{+}\right.$891.2588; found 891.2603.

\section{Acknowledgements}

We thank the Danish Council for Strategic Research for financial support (SET4Future project, grant 0603-00463B). In addition, The NMR Center - DTU and the Villum Foundation are acknowledged for access to the $800 \mathrm{MHz}$ spectrometer.

Keywords: Glycosylation • Hemicellulose • Oligosaccharides • Synthetic methods $\cdot$ Thioglycosides

[1] H. V. Scheller, P. Ulvskov, Ann. Rev. Plant Biol. 2010, 61, 263-289.

[2] Biermann's Handbook of Pulp and Paper: Raw Material and Pulp Making (Ed.: P. Bajpai), Elsevier, Amsterdam, 2018, pp. 19-74.

[3] P. Biely, S. Singh, V. Puchart, Biotechnol. Adv. 2016, 34, 1260-1274.

[4] H. Yagi, T. Maehara, T. Tanaka, R. Takehara, K. Teramoto, K. Yaoi, S. Kaneko, J. Appl. Glycosci. 2017, 64, 115-121.

[5] a) T. Maehara, H. Yagi, T. Sato, M. Ohnishi-Kameyama, Z. Fujimoto, K. Kamino, Y. Kitamura, F. St. John, K. Yaoi, S. Kaneko, Appl. Environ. Microbiol. 2018, 84, e01850-17; b) R. Yan, T. V. Vuong, W. Wang, E. R Master, Enzyme Microb. Technol. 2017, 104, 22-28.

[6] M. C. Jonathan, J. DeMartini, S. Van Stigt Thans, R. Hommes, M. A. Kabel, Biotechnol. Biofuels 2017, 10,112.

[7] M. Chemin, A.-L. Wirotius, F. Ham-Pichavant, G. Chollet, D. Da Silva Perez, M. Petit-Conil, H. Cramail, S. Grelier, Eur. Polym. J. 2015, 66, 190-197.

[8] a) H. Togashi, A. Kato, K. Shimizu, Carbohydr. Polym. 2009, 78, 247252; b) M. K. Nacos, P. Katapodis, C. Pappas, D. Daferera, P. A Tarantilis, P. Christakopoulos, M. Polissiou, Carbohydr. Polym. 2006, $66,126-134$; c) P. Katapodis, S. Kintzios, J. Konstas, D. Kekos, B. J. Macris, P. Christakopoulos, J. Biosci. Bioeng. 2003, 95, 630-632; d) M. A. Verbruggen, B. A. Spronk, H. A. Schols, G. Beldman, A. G. J. Voragen, J. R. Thomas, J. P. Kamerling, J. F. G. Vliegenthart Carbohydr. Res. 1998, 306, 265-274.

[9] T. Yamasaki, A. Enomoto, A. Kato, T. Ishii, M. Kameyama, H. Anzai, K. Shimizu, Carbohydr. Polym. 2012, 87, 1425-1432.

[10] C. Kinnaert, M. Daugaard, F. Nami, M. H. Clausen, Chem. Rev. 2017, 117, 11337-11405.

[11] a) S. Oscarson, P. Svahnberg, J. Chem. Soc., Perkin Trans. 12001 , 873-879; b) Y. Kawabata, Y. Gama, I. Kusakabe, Biosci. Biotech Biochem. 1994, 58, 1463-1466; c) P. Kováč, E. Petráková, P. Kočiš, Carbohydr. Res. 1981, 93, 144-147; d) J. Hirsch, P. Kováč, J. Alföldi, V. Mihálov, Carbohydr. Res. 1981, 88, 146-152.

[12] P. Kováč, J. Hirsch, V. Kováčik, P. Kočiš, Carbohydr. Res. 1980, 85, 41-49.

[13] E. N. Underlin, M. Böhm, R. Madsen, J. Org. Chem. 2019, 84, 1603616054.

[14] a) B. Yang, W. Yang, S. Ramadan, X. Huang, Eur. J. Org. Chem. 2018, 1075-1096; b) W. Yang, B. Yang, S. Ramadan, X. Huang, Beilstein J. Org. Chem. 2017, 13, 2094-2114.

[15] D. Crich, F. Cai, F. Yang, Carbohydr. Res. 2008, 343, 1858-1862.

[16] For an alternative approach to arabinoxylans by automated glycan assembly, see: D. Senf, C. Ruprecht, G. H. M. de Kruijff, S. O. Simonetti, F. Schuhmacher, P. H. Seeberger, F. Pfrengle, Chem. Eur. J. 2017, 23, 3197-3205.

[17] a) J. D. C. Codée, A. E. Christina, M. T. C. Walvoort, H. S. Overkleeft, G. A. van der Marel, Top. Curr. Chem. 2011, 301, 253-289; b) L. J. van den Bos, J. D. C. Codée, R. E. J. N. Litjens, J. Dinkelaar, H. S. Overkleeft, G. A. van der Marel, Eur. J. Org. Chem. 2007, 3963-3976.

[18] a) A. N. Zakharova, R. Madsen, M. H. Clausen, Org. Lett. 2013, 15, 1826-1829; b) M. H. Clausen, R. Madsen, Chem. Eur. J. 2003, 9, 3821
3832; c) M. H. Clausen, M. R. Jørgensen, J. Thorsen, R. Madsen, J. Chem. Soc., Perkin Trans. 1 2001, 543-551.

[19] a) K. Šuchová, S. Kozmon, V. Puchart, A. Malovíková, T. Hoff, K. B. R. M. Krogh, P. Biely, Arch. Biochem. Biophys. 2018, 643, 42-49; b) F. J. St. John, J. C. Hurlbert, J. D. Rice, J. F. Preston, E. Pozharski, J. Mol Biol. 2011, 407, 92-109; c) K. Kolenová, O. Ryabova, M. Vršanská, P. Biely, FEBS Lett. 2010, 584, 4063-4068; d) K. Kolenová, M. Vršanska, P. Biely, J. Biotechnol. 2006, 121, 338-345.

[20] See Supporting Information for details.

[21] K. C. Nicolaou, H. J. Mitchell, K. C. Fylaktakidou, R. M. Rodríguez, H. Suzuki, Chem. Eur. J. 2000, 6, 3116-4148.

[22] S. M. Andersen, M. Heuckendorff, H. H. Jensen, Org. Lett. 2015, 17, 944-947.

[23] D. Crich, Z. Dai, S. Gastaldi, J. Org. Chem. 1999, 64, 5224-5229.

[24] K. Bock, C. Pedersen, Acta Chem. Scand. 1975, B29, 258-264.

[25] See also: M. Alpe, S. Oscarson, Carbohydr. Res. 2003, 338, 26052609.

[26] L. J. van den Bos, J. D. C. Codée, J. C. van der Toorn, T. J. Boltje, J. H. van Boom, H. S. Overkleeft, G. A. van der Marel, Org. Lett. 2004, 6, 2165-2168.

[27] K. Igarashi, J. Irisawa, T. Honma, Carbohydr. Res. 1975, 39, 213-225.

[28] T. Ishii, T. Konishi, T. Yamasaki, A. Enomoto, M. Yoshida, I. Maeda, K Shimizu, Carbohydr. Polym. 2010, 81, 964-968.

[29] K. Bock, C. Pedersen, J. Chem. Soc., Perkin Trans. 2 1974, 293-297.

[30] D. A. Evans, T. C. Britton, J. A. Ellman, Tetrahedron Lett. 1987, 28, 6141-6144.

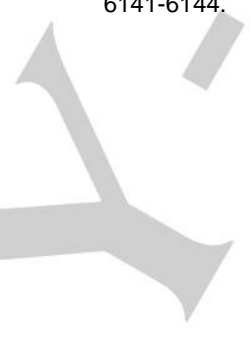




\section{Oligosaccharide Synthesis}

Insert graphic for Table of Contents here.

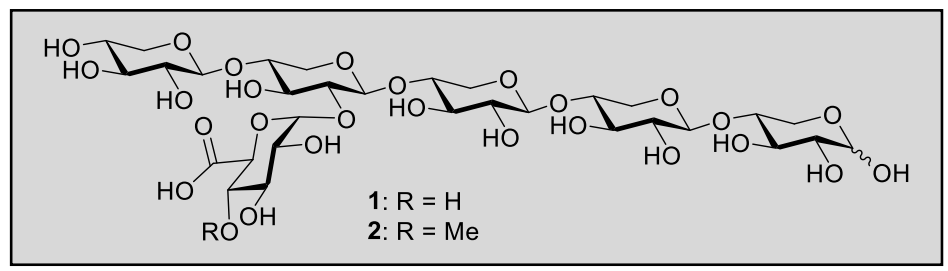

Glucuronoxylans 1 and 2 have been prepared by a concise synthetic route where the pentaxylan backbone is assembled by preactivation-based glycosylations with phenyl thioglycosides and the glucuronic acids are introduced by Koenigs-Knorr couplings 